\title{
Comparison of continuous and pulsed wave lasers in keyhole welding of stainless-steel to aluminium
}

\author{
Julio Coroado $^{1} \cdot$ Supriyo Ganguly ${ }^{1} \cdot$ Stewart Williams $^{1} \cdot$ Wojciech Suder ${ }^{1} \cdot$ Sonia Meco $^{1} \cdot$ Goncalo Pardal $^{1}$
}

Received: 2 July 2021 / Accepted: 14 October 2021 / Published online: 31 October 2021

(C) The Author(s) 2021

\begin{abstract}
A continuous wave $(\mathrm{CW})$ and a nanosecond pulsed wave (PW) lasers were used to join 1-mm thick sheets of SS304L (SS) austenitic stainless-steel to AA5251 (Al) aluminium alloy in an overlap joint configuration. The weld shape (penetration depth and width), intermetallic compounds concentration, weld quality (cracking and porosity) and mechanical strength were correlated with the process energy and compared between each laser temporal mode. Successful CW joints were produced with the SS sheet on top of the Al, but the opposite configuration revealed to be impossible for the range of parameters tested. The PW joints were successful with the Al sheet on top of SS, but all the joints cracked at the interface when the opposite configuration was used. The mechanical tests showed that even though it is possible to achieve higher tensile shear load in $\mathrm{CW}$ welds due to the larger bonding area, the tensile shear strength revealed to be almost $5 \times$ higher for PW welds at similar applied energy.
\end{abstract}

Keywords Dissimilar metal joining $\cdot$ Keyhole laser welding $\cdot$ Intermetallic compounds $\cdot$ Aluminium $\cdot$ Stainless-steel

\section{Introduction}

Dissimilar joining of SS to $\mathrm{Al}$ alloys is widely used in thin gauge materials in aerospace and automotive applications, seeking to improve fuel efficiency through weight reduction. The combination of lightweight $\mathrm{Al}$ alloys and the good corrosion resistance and weldability of SS alloys bring higher quality and economic demand where several material requirements are desired for similar applications, such as electric vehicles (EVs) battery enclosure/housings which contain a large number of cells [1]. However, due to the different physical properties and chemical incompatibility of the alloys, the joining process becomes challenging [2]. The low solid solubility of $\mathrm{Al}$ into iron $(\mathrm{Fe})$ and the almost zero solid solubility of iron into aluminium is responsible for the formation of brittle intermetallic compounds (IMCs). The presence of the IMCs added to the differences in melting point, thermal expansion coefficient, thermal conductivity and specific heat capacity may lead to the formation of brittle intermetallic compounds (IMCs), and consequently

Julio Coroado

julio.coroado@gmail.com

1 Welding Engineering and Laser Processing Centre, Cranfield University, Cranfield MK43 0AL, UK defects such as cracking, causing brittle failure in service due to internal stresses after fusion welding [3]. The formed IMCs have different crystal structures in comparison to the base metals. Solid $\mathrm{Fe}$ and molten $\mathrm{Al}$ reactions are controlled by diffusion [4]. When the temperature on the SS side approaches the Al melting temperature, the diffusion coefficient of $\mathrm{Fe}$ into $\mathrm{Al}$ increases, but the opposite is not verified if SS is still solid.

Temperature and time are the key parameters in the formation and growth of the IMCs [4, 5]. It is not possible to control them independently to minimise the amount of IMCs and maximise the mechanical strength of joints produced, as low heat input leads to less IMCs but also smaller welds and lower strength. Mechanical joining processes such as screwing, riveting, roll bonding or clinching are good alternatives since no IMCs are formed [6, 7]. More recently, friction stir welding, a solid-state joining process, was also successfully employed, avoiding fully molten material [8]. Nevertheless, tool wear and lack of flexibility in the joint geometry are some of the limitations. On the other hand, some fusionbased joining processes such as resistance spot welding and laser-MIG hybrid welding create a large weld pool due to the long thermal cycle, which enhances the IMCs formation [9].

Laser welding is a popular process to join dissimilar materials. The localised energy input of the welding source 
allows a minimal heat-affected zone. The high-cooling rates and short-processing time compared with other techniques reduces the diffusion of $\mathrm{Fe}$ in $\mathrm{Al}$ and thus, the formation of $\mathrm{Fe}-\mathrm{Al}\left(\mathrm{Fe}_{3} \mathrm{Al}, \mathrm{FeAl}_{2}, \mathrm{Fe}_{2} \mathrm{Al}_{3}, \mathrm{Fe}_{2} \mathrm{Al}_{5}, \mathrm{FeAl}_{3}\right)$ [10, 11] and $\mathrm{Al}-\mathrm{Cr}\left(\mathrm{Al}_{4} \mathrm{Cr}, \mathrm{Al}_{8} \mathrm{Cr}_{5}, \mathrm{Al}_{9} \mathrm{Cr}_{4}\right)$ binary compounds commonly formed at the joint interface [12] As an industrially commonly used joining technique, laser welding can be employed in welding applications in automotive battery packs where a laser is used to precisely join small cylindrical cells ( $\leq 0.5 \mathrm{~mm}$ thick) but also large cells with geometrical large interconnectors [1]. Another prominent application associated is the manufacturing of biomedical devices, orthopaedic and prosthetic implants which require in some cases several microscopic welds to join thin materials ( $\leq 1 \mathrm{~mm}$ thick) [13].

There are two types of laser temporal modes: CW and PW. The PW lasers have lower average power but higher peak power on each pulse, leading to high-power density and deep keyhole, being able to create high aspect ratio weld profiles [14] or drilling the material and creating micro-holes if the vaporisation temperature is exceeded [15]. The higher peak power promotes more vaporisation than CW laser for the same average power, which is associated with a rapid energy application within a short duration allows fast material solidification, being better for dissimilar metal joining. Many researchers used lasers to weld dissimilar materials. Huang et al. [16] studied the formation of brittle IMCs using high energy and a high repetition femtosecond laser to join $\mathrm{Al}$ to SS ( $\leq 1 \mathrm{~mm}$ thick). The formation of IMCs was restricted, and crack formation was suppressed due to highly localised heat generation, which minimised the heat input into the material. Yang et al. [17] joined pure $\mathrm{Al}$ and $\mathrm{SS}$ (0.8 mm thick) using a millisecond PW laser. They found that for deeper welds, hard Al-rich IMCs were formed, which deteriorated the strength of the joint. Many micro-cracks were observed in the Al-rich IMCs, and almost no defects were discovered in the Fe-rich IMCs at the joint interface. The two previous studies suggest that different pulse durations can be used to successfully reduce the IMCs formation. However, the results were analysed in terms of system parameters, being difficult for the comparison of both lasers to understand how the Al-rich IMCs should be avoided independently of the laser used. Nanosecond PW lasers can also be used to enhance the joining of $1 \mathrm{~mm}$ thick Al to 0.85 -mm thick steel sheet [18]. Defect-free Fe-Al joints were achieved by laser spot welding using laser-textured steel: first, the surface of steel was textured using a nanosecond PW laser and then, the spot welding process was performed with a defocused and stationary CW laser. The steel plate was positioned on top of the Al sheet with a texture faced down to the Al surface in a lap joint configuration. The results suggested that the maximum tensile shear load was improved due to an increase in the bonding area created by the textured surface and the quality and uniformity of the weld nuggets. Nevertheless, several weld spots or different weld patterns could also have been used to improve the bonding area.

CW laser can also be used for dissimilar welds with good results. Meco et al. [19] successfully minimised the reaction between $\mathrm{Fe}$ and $\mathrm{Al}$ by joining steel to $\mathrm{Al}$ in a lap joint configuration operating a $\mathrm{CW}$ laser in conduction mode. This technique also allowed successful T-joints produced by melting the $\mathrm{Al}$ plate, which was inserted into a steel plate [20]. In a different study, Meco et al. [21] used a FE model to predict the thermal cycle at the interface between steel and $\mathrm{Al}$ plates using different laser parameters. They showed that a small bonding area is equally detrimental to the mechanical strength of the joint as having a thick IMC layer. The FE model suggested that the temperature to which the materials are exposed is more critical than the time, as this is the factor with a higher contribution to the growth of the IMC layer and the formation of the bonding area. The power density was found to be the dominant parameter controlling the peak temperature. Hence, this parameter should be low to avoid high temperatures and consequently brittle IMCs at the joint interface. It is important to note that since the previous studies were performed in terms of power density, interaction time and energy, the results can be equally and easily compared to any other CW laser. Sierra et al. [22] showed that when $\mathrm{Al}$ was placed upon steel, the IMC layer created by a CW laser was larger when compared to the opposite configuration. This was caused due to the increased diffusion of $\mathrm{Fe}$ into molten $\mathrm{Al}$ when the steel plate was still solid. The high concentration of hard and brittle $\mathrm{Fe}_{2} \mathrm{Al}_{5}$ in the $\mathrm{Al}$ interface was detrimental to the strength of the welds [22, 23].

The advancements of the latest generation of fibre pulsed lasers in pulse shape modulation, higher peak powers and shorter pulse durations available can bring advantages in minimising the IMC concentration through fast freezing of the melt pool. Nevertheless, their lower average power in comparison to $\mathrm{CW}$ lasers can be a major drawback for the application in thicker material sheets. The previous studies showed that is possible to achieve good joints between SS and $\mathrm{Al}$ using PW and CW lasers, but the results are case to case sensitive. However, it was not found any direct comparison between both laser temporal modes to quantify which one offers better control of the IMCs at the joint interface, better weld shape flexibility to increase the bonding area and consequently stronger joints. Therefore, it is necessary for like-for-like comparison of both lasers with a systematic and controlled way to achieve large enough joints without overheating the materials.

This research aims to compare continuous wave and pulsed wave to understand how the bond area, weld shape, IMCs distribution and lap joint configuration affect the mechanical 
strength of welds achieved at similar applied energy per unit length.

\section{Definition of the fundamental laser-material interaction parameters}

To enable like-for-like comparison between $\mathrm{CW}$ and $\mathrm{PW}$ lasers, a concept of fundamental laser-material interaction parameters (FLMIP) has been used this work [24-26]. These parameters fully describe the laser-material interaction, allowing the replication of similar weld shapes in different laser systems operated in CW mode [24, 25] and PW mode [26] because they control the weld thermal cycle [27].

The application of energy per unit length on the material is well defined for CW mode. However, as shown in Fig. 1, in nanosecond PW seam welding, the energy is delivered in the form of individual pulses or trains of pulses with characteristic pulse energy $\left(E_{\text {pulse }}\right)$, peak power and pulse duration $\left(P_{\text {Width }}\right)$. Since the peak power is only instantaneous, similarly to previous studies [28,29], this work has also considered the average peak power for pulse energy calculation purposes.

In CW mode, the process can be specified using power density $\left(q_{p}\right)$, interaction time $\left(t_{i}\right)$ and specific point energy $\left(E_{\mathrm{SP}}\right)$, as given by Eqs. (1-3) [27]. The first one is determined as the ratio of the laser average power $\left(P_{L}\right)$ to the area of the laser spot on the material's surface $\left(A_{S}\right)$, which for a circular beam diameter is given by Eq. (1). The interaction time is defined as the ratio of the beam diameter $(d)$ in the welding direction to the travel speed (v), given by Eq. (2). The energy delivered to any specific point on the weld centreline is equal to the product of power density, interaction time and the area of the laser spot on the surface, as given by Eq. (3).

$q_{p}=\frac{P_{L}}{A_{s}}\left[\mathrm{MW} / \mathrm{cm}^{2}\right]$

$t_{i}=\frac{d}{v}[\mathrm{~ms}]$

$E_{S P}=q_{p} \times t_{i} \times A s=P_{\mathrm{L}} \times t_{i}[J]$

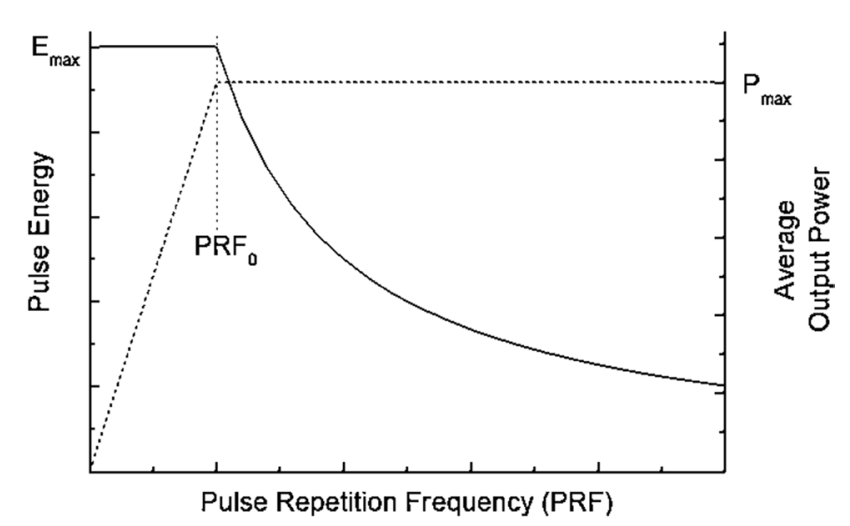

Fig. 2 Output characterisation of the nanosecond PW laser [28]

The output characterisation of the nanosecond PW laser used in this work is shown in Fig. 2. Each temporal mode, referred to as waveform, has optimum pulse repetition frequency $\left(\mathrm{PRF}_{0}\right)$ where the average peak power $\left(P_{\text {peak }}\right)$ and pulse energy are maximum. Since the pulse energy is the ratio between average power and pulse repetition frequency, as given by Eq. (4), the maximum laser average power of $100 \mathrm{~W}$ [31] can be achieved above $\mathrm{PRF}_{0}$, but the pulse energy decreases as the frequency increases. Consequently, the average peak power (ratio between pulse energy and pulse width), decreases in the same proportion for constant pulse width, as given by Eq. (5). Below PRF0, it is possible to achieve constant peak power and pulse energy, but the average power decreases proportionally to the frequency [31]. The duty cycle has different limits depending on the average peak power selected. The percentage of overlap between consecutive spots is defined as the overlap factor and is given in Eq. (6) [32].

$E_{\text {pulse }}=P_{L} / \mathrm{PRF}[J]$

$P_{\text {peak }}=E_{\text {pulse }} / P_{\text {width }}[W]$

$O_{F}=\left(1-\frac{v}{d \times \mathrm{PRF}}\right) \times 100[\%]$

The analysis of the PW welding results was also made using FLMIP: However, in PW mode, the interaction time
Fig. 1 Differentiation of lasers in terms of temporal outputs in continuous wave and modulated pulsed wave mode [30]
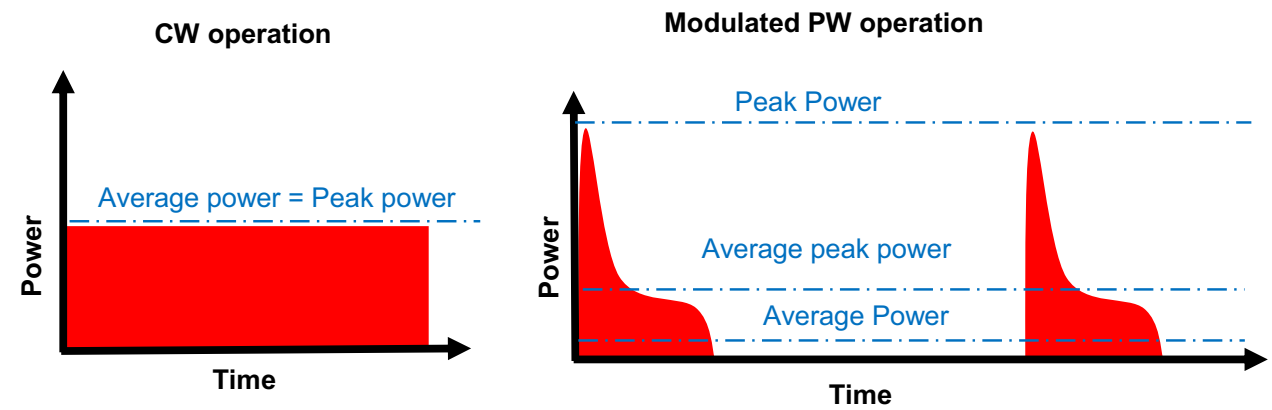
defines the time in which a point is exposed to the laser beam in the weld centreline. It is dependent on the duration of each pulse and the overlap between them, as given by Eq. (7). At $0 \%$ overlap factor, the interaction time is equal to pulse width and at $100 \%$ the equation is not applicable, since the beam is stationary. Hence, Eq. (7) is only applicable below $100 \%$ of overlapping factor [18]. As previously explained in Fig. 2, $P_{\text {peak }}$ change with PRF for constant average power. Therefore, the average peak power density $\left(q_{p \text {, peak }}\right)$ in Eq. (8) is defined by the ratio of $P_{\text {peak }}$ by the area of the laser spot, whereas the specific pulse energy $\left(E_{S P, \text { pulse }}\right)$ in Eq. (9) represents the overall energy delivered by several pulses for a certain laser-material interaction time.

$t_{i}=\left(\frac{P_{\text {width }}}{1-\frac{O_{f}}{100}}\right)[\mathrm{ms}]$

$q_{p, \text { peak }}=\frac{P \text { peak }}{A_{s}}\left[\mathrm{MW} / \mathrm{cm}^{2}\right]$

$E_{S P, \text { pulse }}=q_{p, \text { peak }} \times t_{i} \times A s=P_{\text {peak }} \times t_{i}[J]$

\section{Experimental setup}

The welds were carried out in $1 \mathrm{~mm}$ thick $5251 \mathrm{Al}$ alloy and 304L austenitic SS provided by Aalco [33, 34]. The chemical composition of each alloy is shown in Table 1 . The physical and mechanical properties are shown in Table 2.

The welding configuration used, and corresponding dimensions are shown in Fig. 3. Lap joints were performed positioning SS on top of $\mathrm{Al}$ (SS-Al) and vice versa (Al-SS). According to the literature survey, the IMC grow with temperature and time. A copper heat sink can efficiently extract the heat away from the joint due to its high thermal conductivity, creating a shorter thermal cycle [4]. Consequently, the time for diffusion of the atoms is reduced and the IMCs growth along the joint interface is limited to a smaller area, increasing the likelihood of achieving successful welds [36]. Therefore, a 5-mm thick copper backing bar was used. The welding tests were carried out with two different TRUMPF lasers independently used: a $500 \mathrm{~W}$ average power $\mathrm{CW}$ fibre laser and a $100 \mathrm{~W}$ average power nanosecond pulsed fibre laser. The power of both lasers was measured and calibrated by a laserpoint power meter and the beam profiles were measured using a DataRay slit-scan beam profiler, showing both Gaussian beam profiles. The detailed experimental process is given in Appendix 10.. The 35- $\mu \mathrm{m}$ beam diameters of both lasers were focused using the same $160 \mathrm{~mm}$ f-theta focusing lens connected to a Galvanometer-scanner. An air 
knife was used with compressed gas to protect the lens from spatter, and no shielding gas was applied on the substrate. Before welding, the base materials were ground to remove the oxide layer and residues, and then cleaned with acetone.

\section{Methodology}

\subsection{CW laser welding of SS-AI and AI-SS}

This section aims to investigate the influence of power density $\left(q_{p}\right)$ and specific point energy $\left(E_{S P}\right)$ in the bonding quality of lap welded joints of SS-Al and Al-SS, using a $\mathrm{CW}$ laser. For a constant beam diameter of $35 \mu \mathrm{m}$, different combinations of average power and travel speed were used, resulting in a range of $q_{p}$ from 26 to $49 \mathrm{MW} / \mathrm{cm}^{2}$ and $E_{S P}$ from 137 to $1000 \mathrm{~mJ}$, according to Eqs. (1) and (3), respectively. The set of parameters used are shown in Table 3 . The values presented result from several experiments produced to identify the necessary laser parameters to ensure successful bonding between the base materials.

\subsection{PW laser welding of SS-Al and AI-SS}

A nanosecond PW laser was used to join SS-Al and Al-SS. The aim is to study the influence of average peak power density $\left(q_{p \text {, peak }}\right)$ and specific pulse energy $\left(E_{S P \text {, pulse }}\right)$ in the bonding quality of lap joints and compare the processing
Table.2 Physical and mechanical properties of the base materials [33-35]
Fig. 3 Lap joints dimensions of SS-Al and Al-SS

\begin{tabular}{lllll}
\hline Property & Symbol & Units & Al 5251 H22 & SS304L \\
\hline Density & $\rho$ & $\mathrm{g} / \mathrm{cm}^{3}$ & 2.69 & 8.0 \\
Melting temperature & $T_{m}$ & $\mathrm{~K}$ & 898 & 1723 \\
Vaporisation temperature & $T_{v}$ & $\mathrm{~W} .(\mathrm{m} \cdot \mathrm{K})^{-1}$ & 2790 & 3023 \\
Thermal conductivity average & $k$ & $\mathrm{~W} \mathrm{~m}^{-1} \mathrm{~K}^{-1}$ & 134 & 16.2 \\
Latent heat of melting & $H_{m}$ & $\mathrm{~J}_{\mathrm{kg}} \mathrm{kg}^{-1}$ & $3.5 \times 10^{5}$ & $2.73 \times 10^{5}$ \\
Latent heat of vaporisation & $H_{v}$ & $\mathrm{~J}_{\mathrm{kg}}$ & $1.19 \times 10^{7}$ & $6.1 \times 10^{6}$ \\
Thermal diffusivity average & $\alpha$ & $\mathrm{m}^{2} \mathrm{~s}^{-1}$ & $5.7 \times 10^{-5}$ & $5.5 \times 10^{-6}$ \\
Specific heat of solid phase & $c_{p s}$ & $\mathrm{~J} \cdot \mathrm{kg}^{-1} \cdot \mathrm{K}^{-1}$ & 850 & 477 \\
Viscosity & $\eta$ & $\mathrm{m} . \mathrm{Pas}$ & 1.3 & 8 \\
Modulus of elasticity & $E$ & $\mathrm{GPa}$ & 70 & 193 \\
Proof stress & $\delta$ & $\mathrm{MPa}$ & $120 \mathrm{~min}$ & $220 \mathrm{~min}$ \\
Tensile strength & $\mathrm{UTS}$ & $\mathrm{MPa}$ & $190-230$ & $520-700$ \\
\hline
\end{tabular}

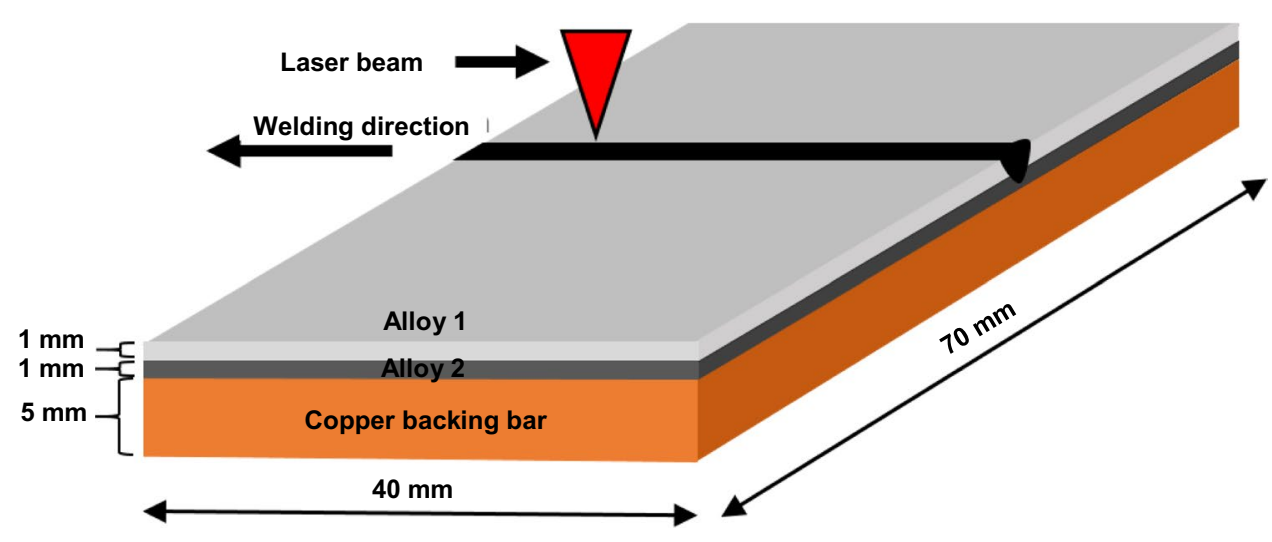

Table.3 CW laser welding parameters for a beam diameter of $35 \mu \mathrm{m}$

\begin{tabular}{llllll}
\hline \multicolumn{5}{l}{ System Parameters } & \multicolumn{5}{l}{ FLMIP } \\
\hline $\begin{array}{l}\text { Beam diameter } \\
{[\mu \mathrm{m}]}\end{array}$ & $\begin{array}{c}\text { Average power } \\
{[\mathrm{W}]}\end{array}$ & $\begin{array}{c}\text { Travel speed } \\
{[\mathrm{mm} / \mathrm{s}]}\end{array}$ & $\begin{array}{c}\text { Interaction time } \\
{[\mathrm{ms}]}\end{array}$ & $\begin{array}{c}\text { Average power den- } \\
\text { sity }\left[\mathrm{MW} / \mathrm{cm}^{2}\right]\end{array}$ & $\begin{array}{r}\text { Specific point } \\
\text { energy [mJ }]\end{array}$ \\
$\boldsymbol{d}$ & $P_{L}$ & $v$ & $t_{i}$ & $q_{p}$ & $E_{S P}$ \\
35 & $250-472$ & $11-94$ & $0.40-3.2$ & $26-49$ & $137-100$ \\
\hline
\end{tabular}


Table.4 Characteristics of waveform 31 of PW laser

\begin{tabular}{lllll}
\hline Waveform & $\mathrm{PRF}_{0}(\mathrm{kHz})$ & $\begin{array}{l}\text { Max pulse } \\
\text { energy, } E_{\max } \\
(\mathrm{mJ})\end{array}$ & $\begin{array}{l}\text { Pulse width } \\
(\mathrm{ns})\end{array}$ & $\begin{array}{l}\text { Peak power at } \\
E_{\max }(\mathrm{kW})\end{array}$ \\
\hline 31 & 100 & 1 & 500 & 7 \\
\hline
\end{tabular}

parameters to achieve similar PW and CW welds. Only one waveform with maximum pulse energy and longest pulse duration available in the laser has been selected. Its characteristics are shown in Table 4. For a constant beam diameter of $35 \mu \mathrm{m}$, an average power of $100 \mathrm{~W}$ and pulse width of $500 \mathrm{~ns}$, different combinations of peak power, pulse energy, travel speed and pulse repetition frequency were used, resulting in a constant $q_{p}$ of $10.4 \mathrm{MW} / \mathrm{cm}^{2}$ and a range of $q_{p \text {, peak }}$ from 33 to $208 \mathrm{MW} / \mathrm{cm}^{2}$ and $E_{S P \text {, pulse }}$ from 250 to $1000 \mathrm{~mJ}$, according to Eqs. (1), (8) and (9), respectively. The set of parameters used are shown in Table 5.

\subsubsection{Mechanical strength characterisation}

Tensile shear tests were carried out to analyse the mechanical strength of selected successful joints from Table 3 and Table 5 for $\mathrm{CW}$ and PW mode, respectively. The maximum load and maximum load per unit of length of the welds were compared between both laser-processing modes for similar applied energies. The ultimate tensile strength (UTS) was also calculated for the strongest joint achieved in each mode by dividing the maximum load by the area of the weld crosssection. The tests were performed at room temperature using an electromechanical Instron 5500 machine, with a load cell of $3 \mathrm{kN}$ and a crosshead displacement of $0.5 \mathrm{~mm} / \mathrm{min}$ perpendicular to the weld direction. The geometry and dimensions of the cross-weld lap tensile shear test specimens were compliant with ISO 14273:2001 standards for mechanical tensile shear testing of seam welds [37]. Figure 4 shows the weld lines patterns used for the tensile testing. The test sample was straight-lined, $25 \mathrm{~mm}$ wide and $160 \mathrm{~mm}$ long. The different numbers of 25 -mm-long horizontal weld line patterns were used: (a) single line, (b) 2 lines and (c) 4 lines, separated by $5 \mathrm{~mm}$ each. The elongation of the parent metals was measured using a laser extensometer model LE-15, for a gauge length of $30 \mathrm{~mm}$.

\subsubsection{Metallographic characterisation}

The cross-sections were mounted in plastic moulds using an epoxy resin mixed with a hardener, ground and then polished to a mirror-like surface. The microstructure of aluminium was revealed by etching its surface with Keller's reagent, whereas SS was electrolytically etched with $10 \%$ of oxalic acid. Micrographs were taken with an Optiphot optical microscope with several magnification levels. A

Table.5 PW laser welding parameters for a beam diameter of $35 \mu \mathrm{m}$, average power of $100 \mathrm{~W}$ and pulse width of $500 \mathrm{~ns}$

\begin{tabular}{|c|c|c|c|c|c|c|c|c|c|}
\hline \multicolumn{4}{|c|}{ System parameters } & \multicolumn{2}{|c|}{ Calculated parameters } & \multicolumn{4}{|l|}{ FLMIP } \\
\hline $\begin{array}{l}\text { Frequency } \\
(\mathrm{kHz})\end{array}$ & $\begin{array}{l}\text { Travel } \\
\text { speed } \\
(\mathrm{mm} / \mathrm{s})\end{array}$ & $\begin{array}{l}\text { Pulse energy } \\
\text { (mJ) }\end{array}$ & $\begin{array}{l}\text { Peak power } \\
(\mathrm{kW})\end{array}$ & $\begin{array}{l}\text { Overlap fac- } \\
\text { tor }(\%)\end{array}$ & $\begin{array}{l}\text { Duty cycle } \\
(\%)\end{array}$ & $\begin{array}{l}\text { Average } \\
\text { power den- } \\
\text { sity (MW/ } \\
\left.\mathrm{cm}^{2}\right)\end{array}$ & $\begin{array}{l}\text { Average peak } \\
\text { power den- } \\
\text { sity (MW/ } \\
\mathrm{cm}^{2} \text { ) }\end{array}$ & $\begin{array}{l}\text { Specific } \\
\text { pulse energy } \\
(\mathrm{mJ})\end{array}$ & $\begin{array}{l}\text { Interac- } \\
\text { tion time } \\
(\mathrm{ms})\end{array}$ \\
\hline PRF & $v$ & $E_{\text {Pulse }}$ & $P_{\text {peak }}$ & $O_{F}$ & $\mathrm{DC}$ & $q_{p}$ & $q_{p, \text { peak }}$ & $E_{S P, \text { pulse }}$ & $t_{i}$ \\
\hline $100-807$ & $3.5-14$ & $0.12-1.0$ & $0.25-2.0$ & 99.9-99.98 & $5-40.4$ & 10.4 & $26-208$ & $250-1000$ & $0.5-3.2$ \\
\hline
\end{tabular}

Fig. 4 Pattern of weld lines used for tensile testing

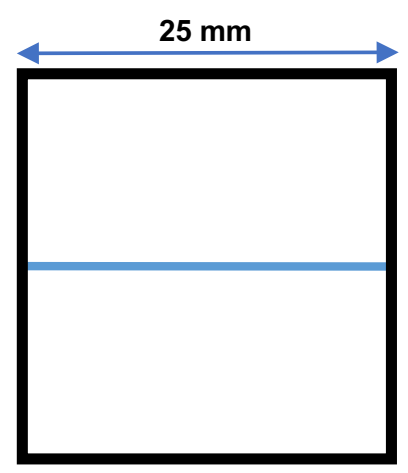

a

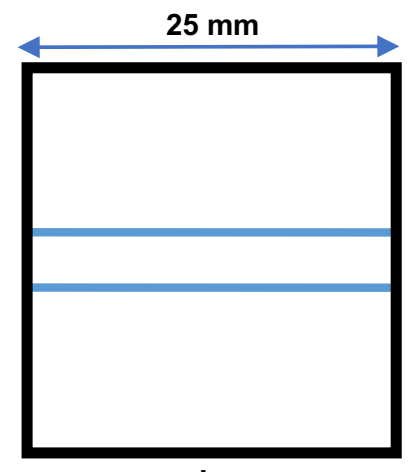

b

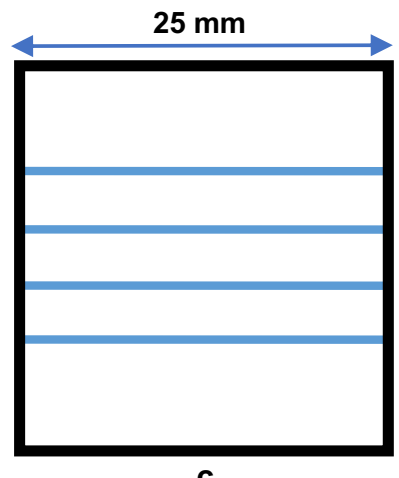

C 
scanning electron microscope (SEM) equipment was also used to investigate the composition and distribution of the IMC on the fusion zone of the welds with integrated energydispersive $\mathrm{X}$-ray spectroscopy (EDS).

\section{Results and discussion}

\subsection{CW laser welding of SS-Al and AI-SS}

The CW laser was used to join SS-Al in the first stage and then, in a second stage, Al-SS. The welding parameters used are shown in Table 6 .

It is shown in Fig. 5a-c the fusion zone of the lap joints of SS-Al for different levels of specific point energy and constant power density. In Fig. 5d-f, it is shown in more detail the respective joints magnification from Fig. 5a-c. Due to the lower vaporisation temperature of $\mathrm{Al}$ in comparison to SS (Table 2), in Fig. 5a occurred a violent ejection of metal for the highest $E_{S P}$ and $q_{p}$ applied. As $E_{S P}$ decreased from Fig. 5d-f at constant $q_{p}$ through a reduction in $t_{i}$ (Table 6), the penetration depth decreased as well and weld quality was improved, i.e. cracks were reduced. This improvement is related to the IMC formation, since they are dependent on the time and temperature of the process, decreasing with a reduction in energy input [36]. It is important to highlight the difficulty in achieving low energy levels with CW lasers since high travel speeds are required to achieve rapid melting and solidification, and consequently, low IMC formation.

In Fig. 5, the IMC were mixed and not distributed in a thin layer as a needle shape along the interface, as observed in previous studies for laser conduction mode [36, 38, 39]. Since this study has been performed in keyhole mode, the mixing of both alloys was enhanced and the IMCs distributed around the fusion zone, as observed in the EDS mapping in Fig. 6. A several times lower viscosity of $\mathrm{Al}$ as compared to SS (Table 2) must be considered as an important factor to explain how easy Fe diffuses in Al, enhancing their mixing. Moreover, the higher density of SS in comparison to Al (Table 2) may also have facilitated the mixing of both alloys. A similar explanation was given by Lee et al. when they tried to join $\mathrm{Al}$ to copper [40].

It is known that lower power density decreases the reaction rate between $\mathrm{Al}$ and $\mathrm{Fe}$, enabling better control of the IMCs formation [36]. Therefore, in this work, the power density has been decreased from $49 \mathrm{MW} / \mathrm{cm}^{2}$ in Fig. 5 to $33 \mathrm{MW} / \mathrm{cm}^{2}$ in Fig. 7 at constant $E_{S P}$ through a reduction in average power and travel speed (Table 6). As expected, the weld quality has been improved, despite the small cracks caused by the remaining IMCs. Some solute bands of Fe-Al phases are visible on the edge of the weld. These bands have also been observed by Sierra et al. when joining steel to Al using a high-power CW laser [22]. They attributed their origin to the upward convection movements occurring at high temperatures, entrapping $\mathrm{Al}$ in steel. A rise in the volume of liquid Al due to the increase of steel penetration led to a greater $\mathrm{Al}-\mathrm{Fe}$ dilution, which resulted in thicker bands, as observed in Fig. 7d. These bands could form (1) locally richer aluminium $\mathrm{Fe}-\mathrm{Al}$ alloys, (2) $\mathrm{Fe}_{\mathrm{x}} \mathrm{Al}_{\mathrm{y}}$ intermetallic phases if the formation threshold had been reached, or (3) could solidify as pure Al [22].

Table.6 Laser welding parameters and results for a beam diameter of $35 \mu \mathrm{m}$

\begin{tabular}{|c|c|c|c|c|c|c|c|}
\hline \multicolumn{3}{|c|}{ System Parameters } & \multicolumn{3}{|l|}{ FLMIP } & \multicolumn{2}{|c|}{ Successful bonding? } \\
\hline $\begin{array}{l}\text { Beam diameter } \\
{[\mu \mathrm{m}]}\end{array}$ & $\begin{array}{l}\text { Average power } \\
\text { [W] }\end{array}$ & $\begin{array}{l}\text { Travel speed } \\
{[\mathrm{mm} / \mathrm{s}]}\end{array}$ & $\begin{array}{l}\text { Interaction time } \\
{[\mathrm{ms}]}\end{array}$ & $\begin{array}{l}\text { Average power den- } \\
\text { sity }\left[\mathrm{MW} / \mathrm{cm}^{2}\right]\end{array}$ & $\begin{array}{l}\text { Specific point } \\
\text { energy }[\mathrm{mJ}]\end{array}$ & SS-Al lap joint & Al-SS lap joint \\
\hline$d$ & $P_{L}$ & $v$ & $t_{i}$ & $q_{p}$ & $\mathrm{E}_{\mathrm{SP}}$ & - & - \\
\hline 35 & 250 & 64 & 0.55 & 26 & 137 & No & No \\
\hline 35 & 250 & 32 & 1.1 & 26 & 273 & Yes & No \\
\hline 35 & 250 & 16 & 2.2 & 26 & 545 & Yes & No \\
\hline 35 & 304 & 64 & 0.55 & 32 & 166 & No & No \\
\hline 35 & 304 & 32 & 1.1 & 32 & 333 & Yes & No \\
\hline 35 & 304 & 16 & 2.2 & 32 & 665 & Yes & No \\
\hline 35 & 320 & 64 & 0.50 & 33 & 176 & Yes & No \\
\hline 35 & 320 & 41 & 0.90 & 33 & 273 & Yes & No \\
\hline 35 & 320 & 34 & 1.0 & 33 & 333 & Yes & No \\
\hline 35 & 320 & 22 & 1.6 & 33 & 516 & Yes & No \\
\hline 35 & 320 & 11 & 3.2 & 33 & 1000 & Yes & No \\
\hline 35 & 472 & 94 & 0.40 & 49 & 176 & Yes & No \\
\hline 35 & 472 & 64 & 0.50 & 49 & 258 & Yes & No \\
\hline 35 & 472 & 32 & 1.1 & 49 & 516 & No & No \\
\hline
\end{tabular}




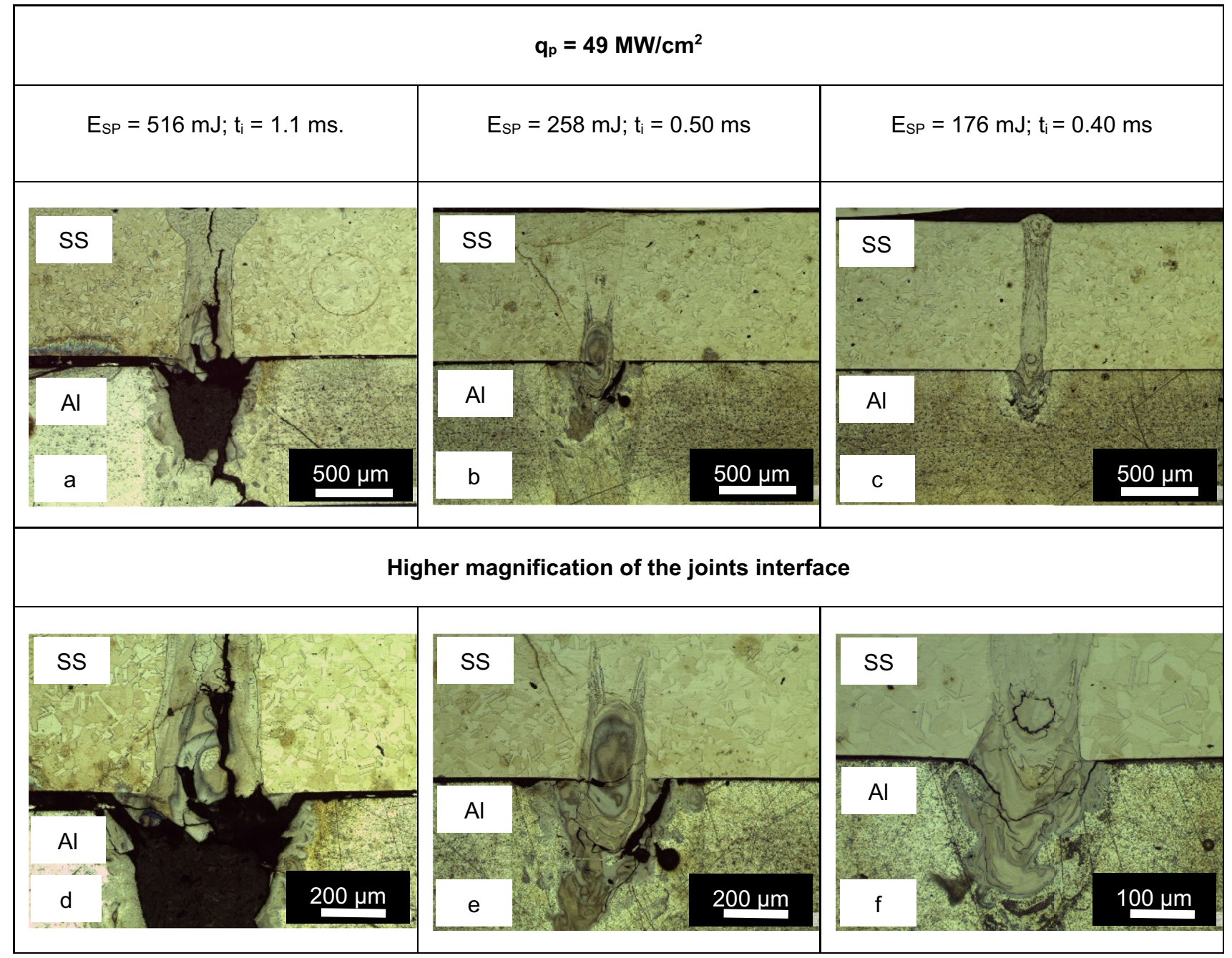

Fig. $5 \mathrm{CW}$ lap joints of SS-Al for constant $q_{p}$ of $49 \mathrm{MW} / \mathrm{cm}^{2}$ and different $E_{S P}$ and $t_{i}$

Fig. 6 EDS mapping of Fe and $\mathrm{Al}$ elements from a CW lap joint of SS-Al for $q_{p}$ of $49 \mathrm{MW} /$ $\mathrm{cm}^{2}, E_{S P}$ of $176 \mathrm{~mJ}$ and $t_{i}$ of $0.4 \mathrm{~ms}$
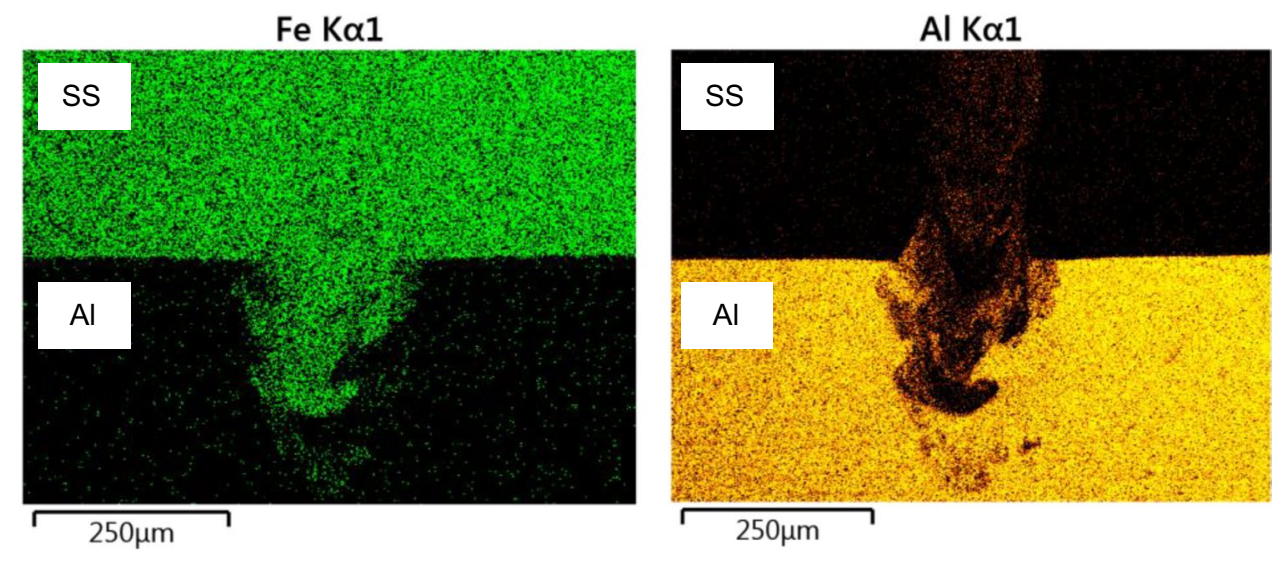

The IMCs distribution from Fig. $7 \mathrm{f}$ was analysed in EDS spectrums in Fig. 8. Spectrum number 34 shows that, in the stainless-steel sheet, there is a small concentration of $\mathrm{Al}$ and no cracks are visible in this region. At spectrum number 37, the concentration of $\mathrm{Al}$ increased slightly, and the formation of the cracks is more evident. Moving further into Al to spectrum number 38 , the atomic percentage of $\mathrm{Al}$ is even higher and very similar to $\mathrm{Fe}$, which 


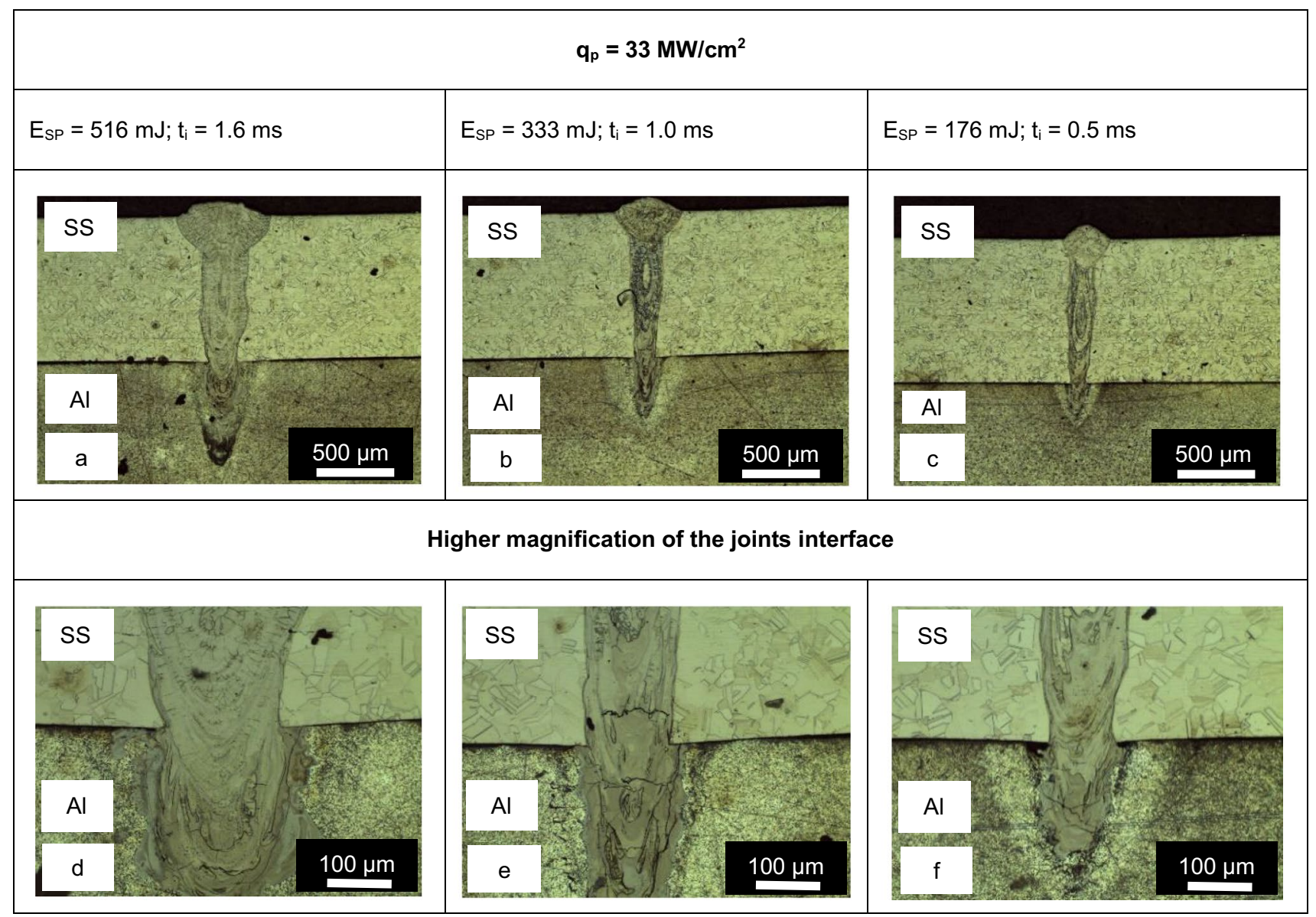

Fig. $7 \mathrm{CW}$ lap joints of SS-Al for constant $q_{p}$ of $33 \mathrm{MW} / \mathrm{cm}^{2}$ and different $E_{S P}$ and $t_{i}$

coincides with the increase of the size of the cracks. However, due to the scattered intermetallic compounds, close to the edge of the joint interface on spectrum number 43 , the atomic percentage of $\mathrm{Al}$ is also high, and a small crack is visible. This is caused by the high peak temperature generated by the high-power density applied in a small beam, resulting in a rise in the recoil pressure, causing upward convection of $\mathrm{Al}$ [28].

The IMCs are organised into two groups, the Fe-rich and the Al-rich IMCs. The hardest and thus more brittle IMCs are found in the Al-rich group [39, 41] for an atomic concentration (at) of $\mathrm{Al}$ above 58\%. Sierra et al. [22] observed that the hardness and consequently, the formation of the cracks, increased in steel-on-aluminium laser welds for deeper penetrations, mainly attributed to an increase in $\mathrm{Al}$ ratio in the weld. These conclusions are in agreement with spectrum 34 from Fig. 8b, where the at.\% of $\mathrm{Al}$ is below $10 \%$ and no cracks are visible, being all the $\mathrm{Al}$ dissolved in $\mathrm{Fe}[39,41]$, and also with spectrum 38 , where the at. $\%$ of $\mathrm{Al}$ is close to $40 \%$ and larger cracks can be observed. However, due to the severe $\mathrm{Al}$ gradients across the weld metal area, different IMCs could have been formed at specific locations.
The welding parameters from Fig. 7 were replicated for an Al-SS lap joint configuration and presented in Fig. 9. Despite the reduction of $E_{S P}$ at constant $q_{p}$ from Fig. $9 \mathrm{a}-\mathrm{c}$, no successful lap joints were possible to achieve, breaking at the interface. In Fig. 9a (Al-SS), for specific point energy of $516 \mathrm{~mJ}$ and power density of $33 \mathrm{MW} / \mathrm{cm}^{2}$, the weld width of the upper sheet of $\mathrm{Al}$ was greater as in comparison to Fig. 7a (SS-Al). The higher thermal conductivity by a factor of eight and lower melting temperature by a factor of two of $\mathrm{Al}$ (Table 2), allowed to create of a larger fusion zone in Fig. 9a, conducting the heat faster to SS. On the other hand, for SS-Al in Fig. 7a, similar energy of $516 \mathrm{~mJ}$ took longer to reach the $\mathrm{Al}$ sheet for a similar interaction time of $0.5 \mathrm{~ms}$, since the specific heat capacity of SS is $1.8 \times$ lower than Al. Thus, the peak temperature reached on the joint interface was lower, decreasing the penetration depth and the IMCs concentration in comparison to the Al-SS lap joint in Fig. 9a. This may explain the difference in bonding for both joint configurations. Similar results were observed by Sierra et al. when joining aluminium-on-steel [22]. All welds performed were cracked at the joint interface. The steel interface exhibited large IMCs, more than $50 \mu \mathrm{m}$ thick because the liquid 


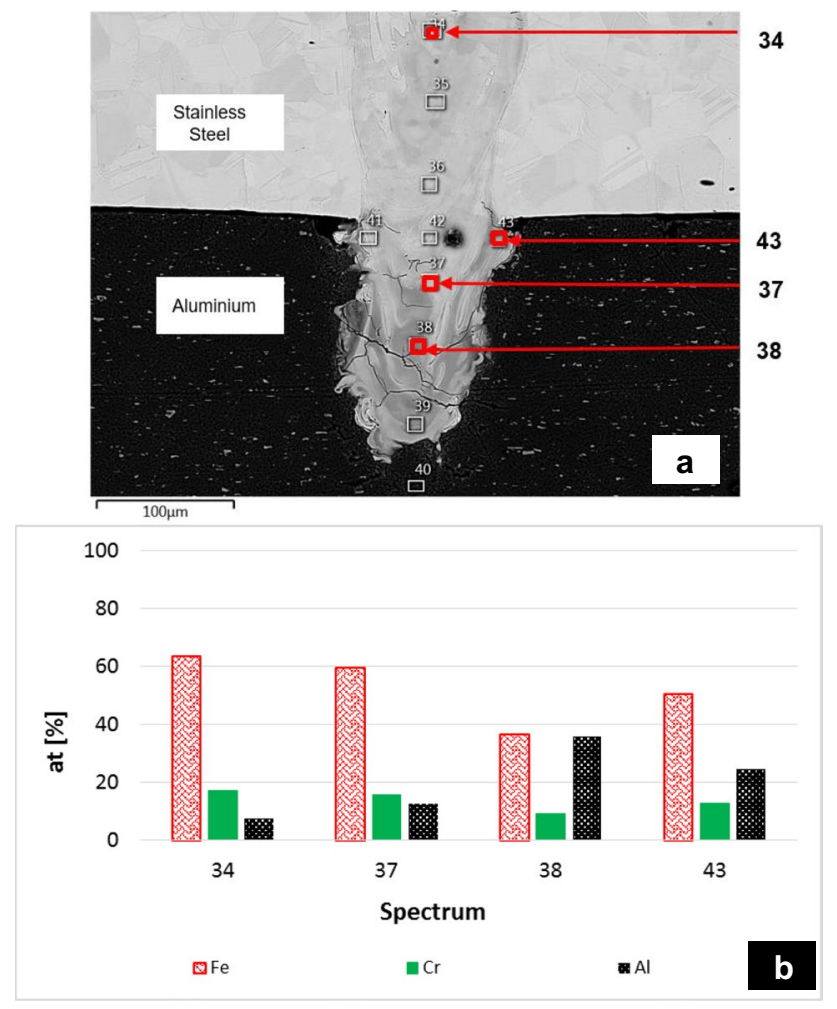

Fig. 8 SEM micrograph (a) and respective EDS spectrum analysis (b) from a CW lap joint of SS-Al for $q_{p}$ of $33 \mathrm{MW} / \mathrm{cm}^{2}, E_{S P}$ of $176 \mathrm{~mJ}$ and $t_{i}$ of $0.5 \mathrm{~ms}$

was richer in steel. They concluded that the cracks were probably related to the sensitivity to hot cracking of the $\mathrm{Al}$ alloys used in their study.

\subsection{PW laser welding of SS-AI and AI-SS}

In this section, a PW laser was used to join SS-Al in the first stage and then Al-SS in the second stage. The welding parameters used are shown in Table 7.

In Figure 10a is shown a PW lap joint of SS-Al for $q_{p \text {, peak }}$ of $208 \mathrm{MW} / \mathrm{cm}^{2}$ and $E_{S P}$, pulse of $1000 \mathrm{~mJ}$. The respective EDS spectrum analysis is shown in Fig. 10b. Several voids can be observed along the fusion zone in Fig. 10a. Magnesium is one of the main alloying elements of the Al alloy used in this study (Table 1). Since the vaporisation temperature of magnesium $(1363 \mathrm{~K})$ is much lower than SS (3023 K) and $\mathrm{Al}(2790 \mathrm{~K})$, its vaporisation may have a strong contribution to the keyhole instability, increasing the capillary forces generated and the likelihood of defect formation in the weld pool [29, 42]. The lower viscosity of $\mathrm{Al}$ as compared to SS also enables more efficient melt removal from the bottom of the keyhole [35].

The EDS spectrum analysis from Fig. 10b indicates a high concentration of $\mathrm{Fe}$ in the centre of the SS sheet, being residual the atomic percentage of $\mathrm{Al}$. However, on the edge of the same horizontal line, the atomic percentage of $\mathrm{Al}$ is $49 \%$. On the $\mathrm{Al}$ sheet, in the middle of the fusion zone, the atomic percentage of $\mathrm{Al}$ is almost $100 \%$. The presence of voids caused by the entrapment of the vaporised alloys after solidification enhanced the mixing of both metals at the interface [43] where the atomic percentage of $\mathrm{Al}$ is above $70 \%$. For these $\mathrm{Al}$ percentages, $\mathrm{F}_{2} \mathrm{Al}_{5}$ and $\mathrm{FeAl}_{3}$ phases were formed [12, 39, 41]. The low fracture toughness of each phase may explain the lack of bonding between these alloys for the parameters tested due to crack formation [43].

The SS-Al lap joints were unsuccessful using a PW laser, but successful in CW mode, as demonstrated in the previous section. A comparison between both temporal modes is shown in Fig. 11 for a similar penetration depth of $1.2 \mathrm{~mm}$. Despite the lower average power of the PW laser in comparison to the $\mathrm{CW}$ laser, its higher peak power generated a higher average peak power density applied in Fig. 11b, increasing the vaporisation of $\mathrm{Al}$ and its alloying elements. This is likely to cause the escape of the vaporised elements towards the top of the narrow weld, causing a high pressure at the joint interface by a descending stream of molten steel and an ascending stream of molten $\mathrm{Al}$, enhancing the mixing between the base metals and the formation of brittle IMCs. Moreover, the difference in the thermal expansion coefficient of both alloys [3] will force a gap between both sheets, cracking the narrow joint, avoiding the bonding. However, this phenomenon is not so evident in CW mode in Fig. 11a. For a similar interaction time of $0.5 \mathrm{~ms}, \mathrm{CW}$ laser utilises a duty cycle of $100 \%$ at a travel speed of $64 \mathrm{~mm} / \mathrm{s}$ (Table 6), whereas with PW laser a duty cycle of $15 \%$ and a travel speed of $10.5 \mathrm{~mm} / \mathrm{s}$ are applied. Thus, the thermal losses are lower in CW mode than in PW mode, being possible to achieve similar penetration depth and a larger weld width at lower applied energy. Due to the deeper depth of penetration, a greater volume of SS was mixed in Al, breaking the balance between recoil pressure and surface tension, enhancing the mixing between both alloys at the bottom of the weld, as previously shown in the EDS mapping from Fig. 8. Hence, in $\mathrm{CW}$ mode, most of the brittle IMCs concentrations are shifted away from the joint interface, improving the bonding between both alloys.

The welding parameters from Table 7 have been replicated for Al-SS lap joint configuration and presented in Fig. 12. Decreasing $E_{S P \text {, pulse }}$ and $q_{p \text {, peak }}$ at constant $q_{p}$ and $t_{i}$ through an increase in travel speed and PRF, the penetration depth decreased from Fig. 12a-c and the weld quality was decreased as well, with some cracks being visible at the joint interface in Fig. 12f. Due to Al being positioned on top, its alloying elements are more likely to vaporise and escape from the top of the weld pool, generating capillary forces which drag SS (Fe) into $\mathrm{Al}$, as observed in the EDS mapping from Fig. 13, corresponding to Fig. 12d. Similar results were observed in Fig. 9 for CW mode. 


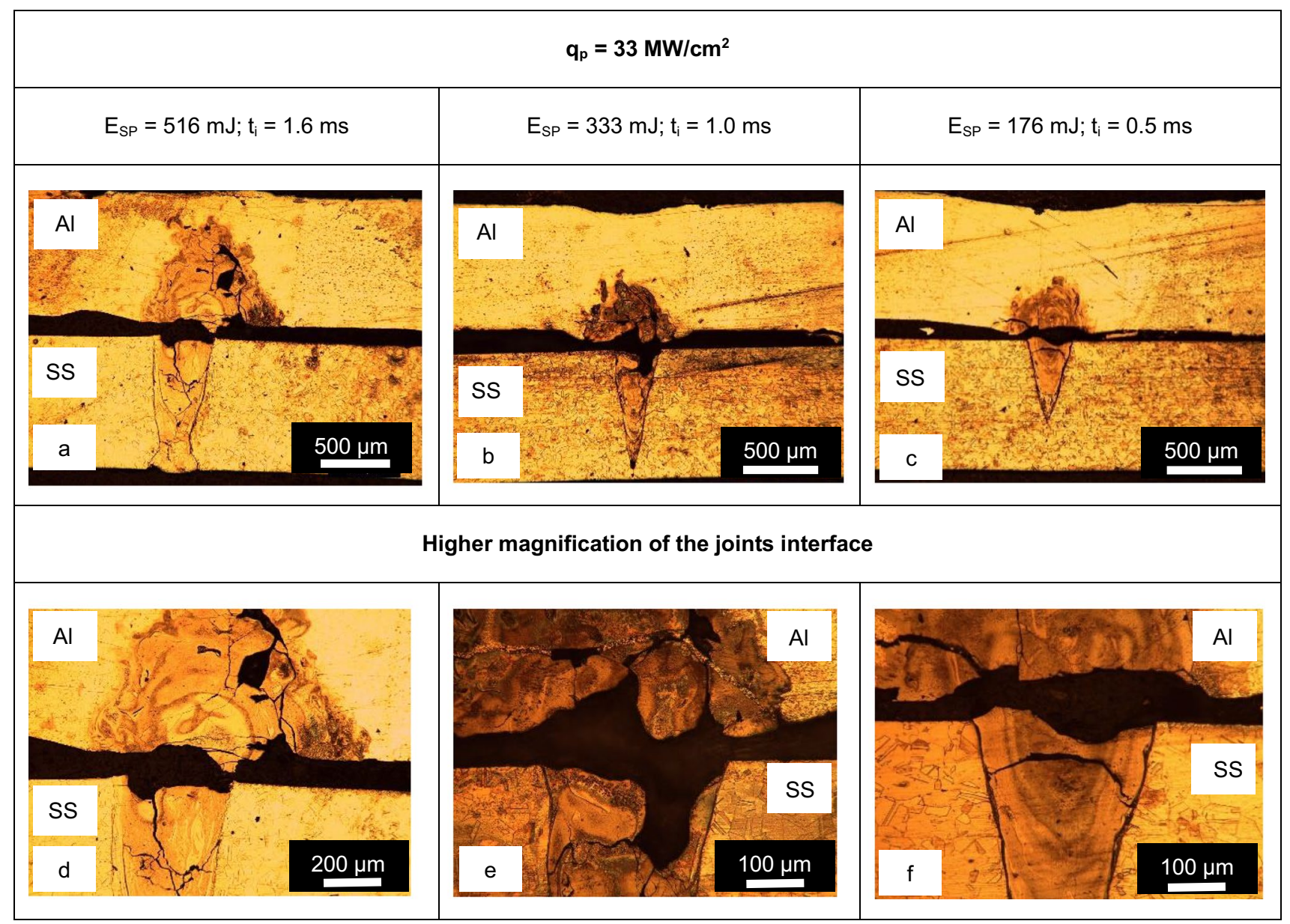

Fig. $9 \mathrm{CW}$ lap joints of Al-SS for constant $q_{p}$ of $33 \mathrm{MW} / \mathrm{cm}^{2}$ and different $E_{S P}$ and $t_{i}$

Several sections from Fig. 12d were analysed in Fig. 14 at the top (Fig. 14a), middle (Fig. 14b) and at the joint interface (Fig. 14c). The corresponding SEM analysis is shown in Fig. 15. In spectrum 67 from Fig. 15, there is a high atomic concentration of $\mathrm{Al}$ in comparison to $\mathrm{Fe}$, whereas, in spectrum 64, the atomic percentage of iron increased. This is likely to be caused by the high peak power density applied in PW mode at a high pulse repetition frequency, which forced the stirring and mixing of $\mathrm{Al}$ in SS, despite the difference in density and viscosity. Consequently, the higher peak temperature in the centre of the beam increased the concentration of $\mathrm{FeAl}_{3}$ in this area, being visible a large crack along the fusion zone. In spectrum 52 from Fig. 15, the concentration of $\mathrm{Al}$ in the fusion zone decreased in comparison to spectrum 64, increasing the concentration of $\mathrm{Fe}$, being formed FeAl phase (iron-rich IMC), which have higher ductility [39, 41]. Consequently, the cracks' size was reduced. At the joint interface, the atomic concentration of $\mathrm{Al}$ is almost inexistent, being dominated by iron, as shown in spectrum 39 . Therefore, most of the $\mathrm{Al}$ is dissolved into $\mathrm{Fe}[39,41]$ and most of the IMCs were shifted away from this region, which is the reason why no cracks are visible.

The EDS spectrum analysis from Fig. 12f is shown in Fig. 16. When the peak power density and specific pulse energy were reduced, the penetration depth and the weld quality were reduced as well, being visible more cracks on the aluminium side. The mixing between both alloys was shifted closer to the joint interface, being formed Al-rich brittle IMCs $\left(\mathrm{Fe}_{2} \mathrm{Al}_{3}\right)[39,41]$, which avoided a successful bonding. It may be possible that the reduction in the applied energy led to a reduction in peak temperature in the molten metal. Since the temperature reduction increases the viscosity of both alloys [35], the capillary forces are reduced, being more difficult for SS to push $\mathrm{Al}$ towards the top of the weld pool. Hence, this may explain why the higher IMC concentration and cracks at the interface.

The PW Al-SS lap joints were successful, but unsuccessful in CW mode, as demonstrated in "Sect. 5.1". A comparison between both temporal modes is shown in Fig. 17 for a similar penetration depth of $1.6 \mathrm{~mm}$. The $\mathrm{CW}$ weld showed in Fig. 17b, needed higher average power density 


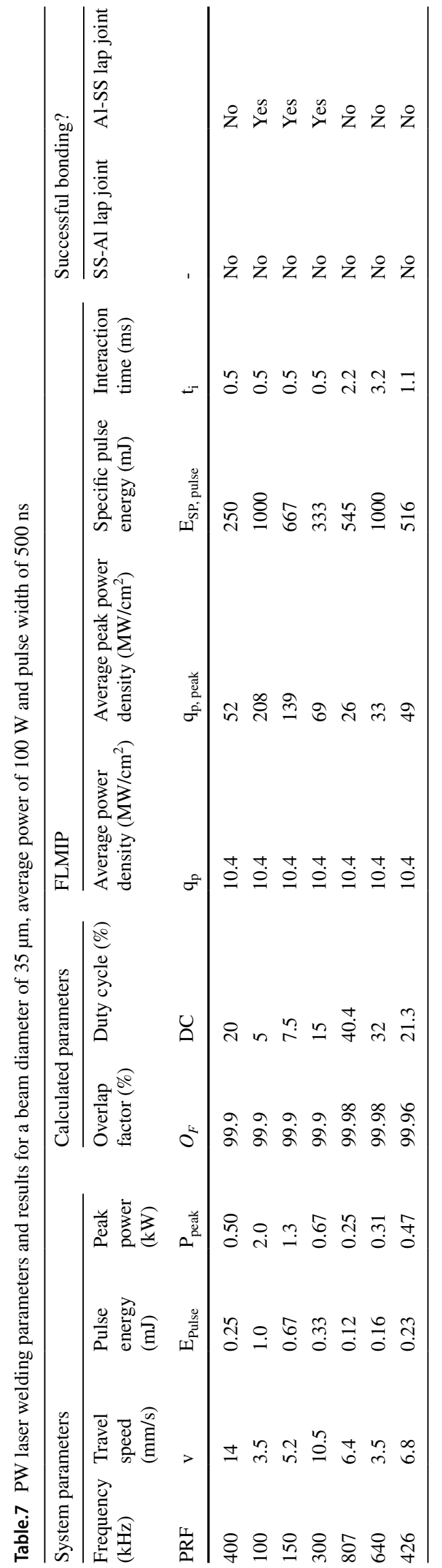

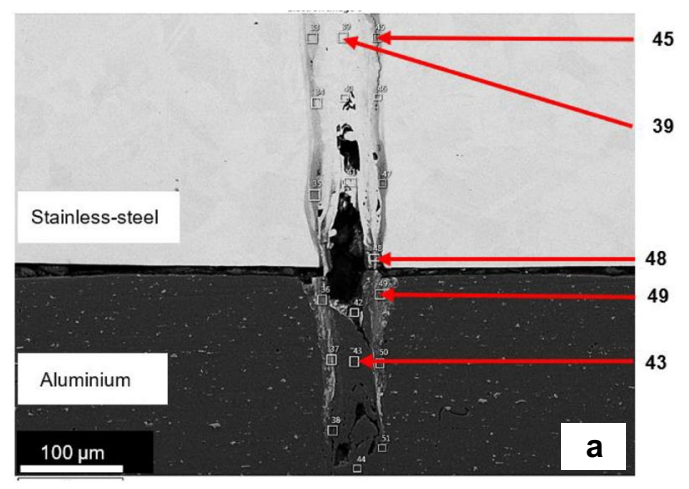

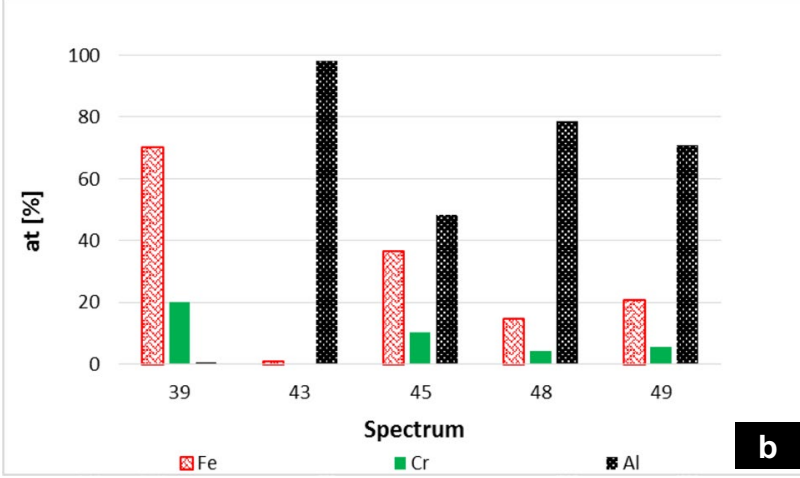

Fig. 10 SEM micrograph (a) and respective EDS spectrum analysis (b) from a PW lap joint of SS-Al for $q_{p}$ of $10.4 \mathrm{MW} / \mathrm{cm}^{2}, q_{p \text {, peak }}$ of $208 \mathrm{MW} / \mathrm{cm}^{2}, E_{S P, \text { pulse }}$ of $1000 \mathrm{~mJ}$ and $t_{i}$ of $0.5 \mathrm{~ms}$

and lower peak power density than the PW laser to open the keyhole in $\mathrm{Al}$, leading to a wide melt pool and consequently, high distortion of the top sheet. Thus, the mix of $\mathrm{Fe}$ and $\mathrm{Al}$ has increased, being the IMCs scattered across a large area. However, in Fig. 17a, the weld width of $\mathrm{Al}$ in PW mode is $10 \times$ smaller than in $\mathrm{CW}$ mode, forcing Fe to displace $\mathrm{Al}$ from the joint interface, as previously observed in the EDS mapping from Fig. 13. This phenomenon was created by the high peak power and low pulse energy applied in short pulses at high frequency. The keyhole formed was able to transfer the heat more efficiently from the Al sheet to SS, being the copper backing bar fundamental to drive the laser energy downwards, providing a narrow melt pool, low distortion, and low diffusion of $\mathrm{Al}$ into Fe. Consequently, the mixing between both alloys in PW mode is shifted away from the joint interface, as previously shown in Fig. 14, allowing successful joints.

\subsection{Mechanical testing}

\subsubsection{Tensile shear load of CW and PW joints}

A subsection of the successful set of parameters from Table 6 and Table 7 was chosen to conduct mechanical tests to evaluate the tensile shear load of $\mathrm{CW}$ and PW joints, 
Fig. 11 SS-Al lap joints for a penetration depth of $1.2 \mathrm{~mm}$ : (a) $\mathrm{CW}$ welding at $q_{p}$ of

$33 \mathrm{MW} / \mathrm{cm}^{2}, E_{S P}$ of $176 \mathrm{~mJ}$ and $t_{i}$ of $0.5 \mathrm{~ms}$; (b) PW welding at $\mathrm{q}_{\mathrm{p}}$ of $10.4 \mathrm{MW} / \mathrm{cm}^{2}, q_{p, \text { peak }}$ of $69 \mathrm{MW} / \mathrm{cm}^{2}, E_{S P, \text { pulse }}$ of $333 \mathrm{~mJ}$ and $t_{i}$ of $0.5 \mathrm{~ms}$
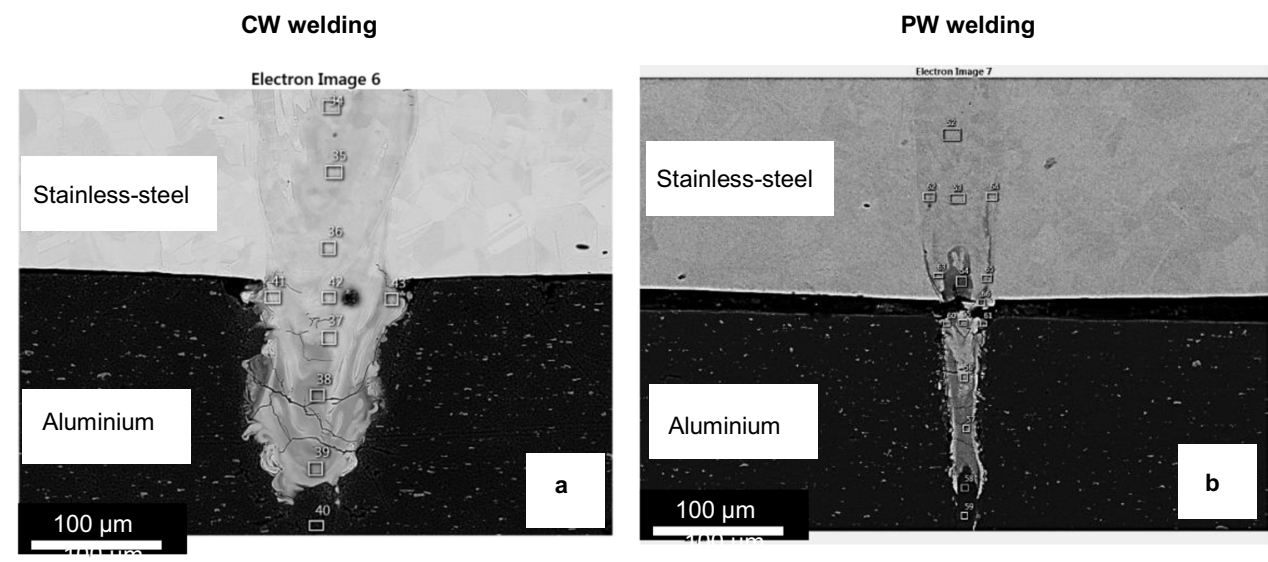

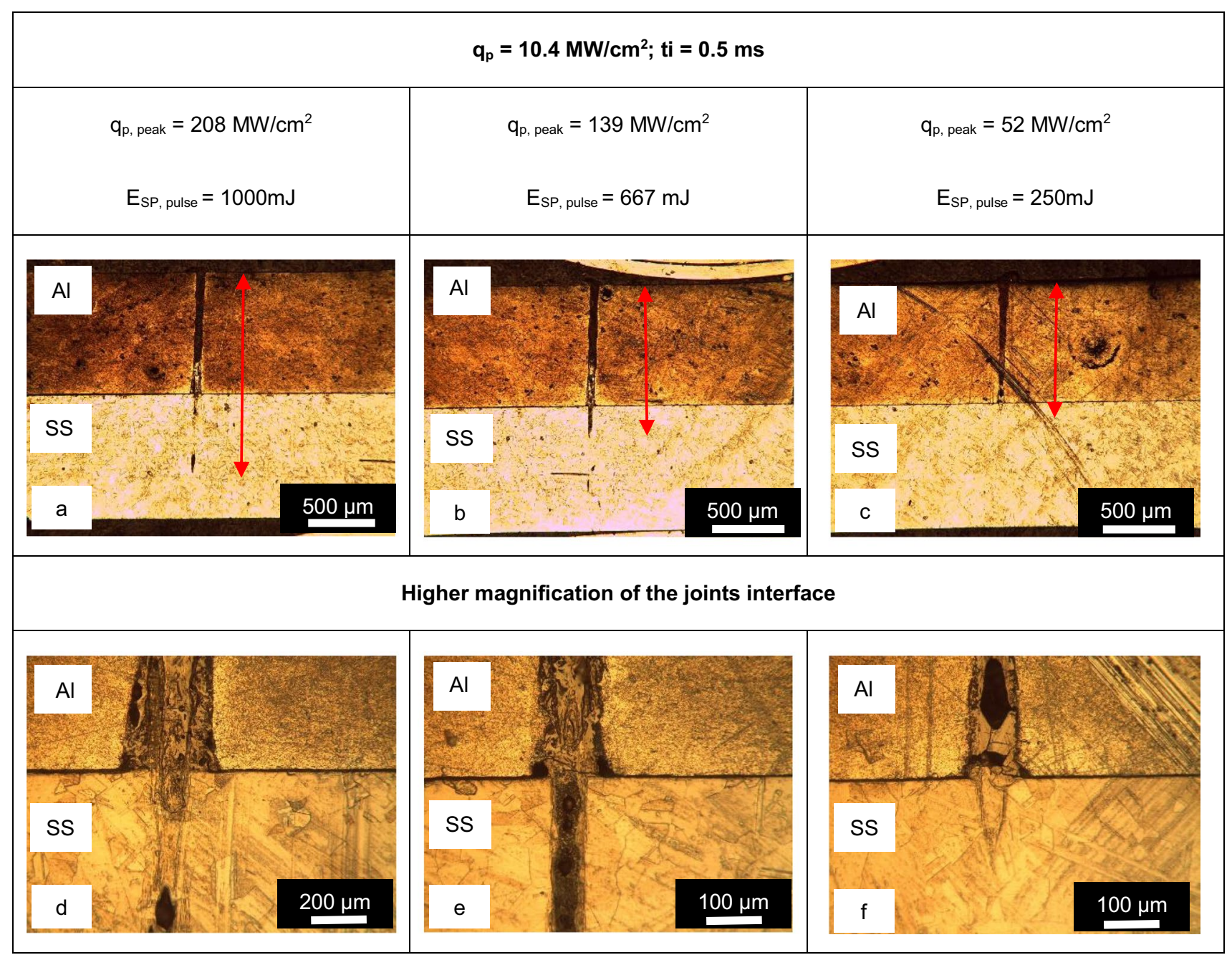

Fig. $12 \mathrm{PW}$ lap joints of Al-SS for constant $q_{p}$ of $10.4, t_{i}$ of $0.5 \mathrm{~ms}$ and different $q_{p \text {, peak }}$ and $E_{S P \text {, pulse }}$

respectively. It is shown in Fig. 18 that, for constant $E_{S P}$ and $q_{p}$, the breaking load of CW welds increases with an increase in the number of weld lines. There is also a trend on the increase of the tensile shear load with the increase of the energy from 333 to $1000 \mathrm{~mJ}$, being possible to reach $1700 \mathrm{~N}$ using four weld lines. This observation may be related to the larger bonding area achieved for a longer thermal cycle, as also reported by Meco et al. [21], creating a 
Fig. 13 EDS mapping of $\mathrm{Fe}$ and $\mathrm{Al}$ elements from a PW lap joint of Al-SS for qp of $10.4 \mathrm{MW} /$ $\mathrm{cm}^{2}, q_{p, \text { peak }}$ of $208 \mathrm{MW} / \mathrm{cm}^{2}$, $E_{S P, \text { pulse }}$ of $1000 \mathrm{~mJ}$ and $t_{i}$ of $0.5 \mathrm{~ms}$
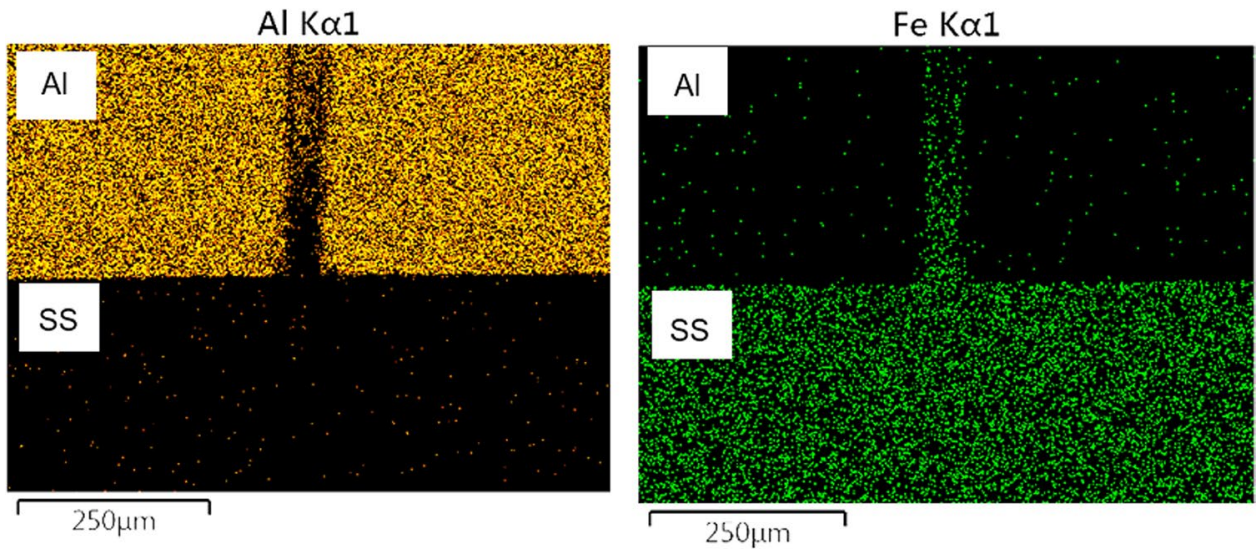

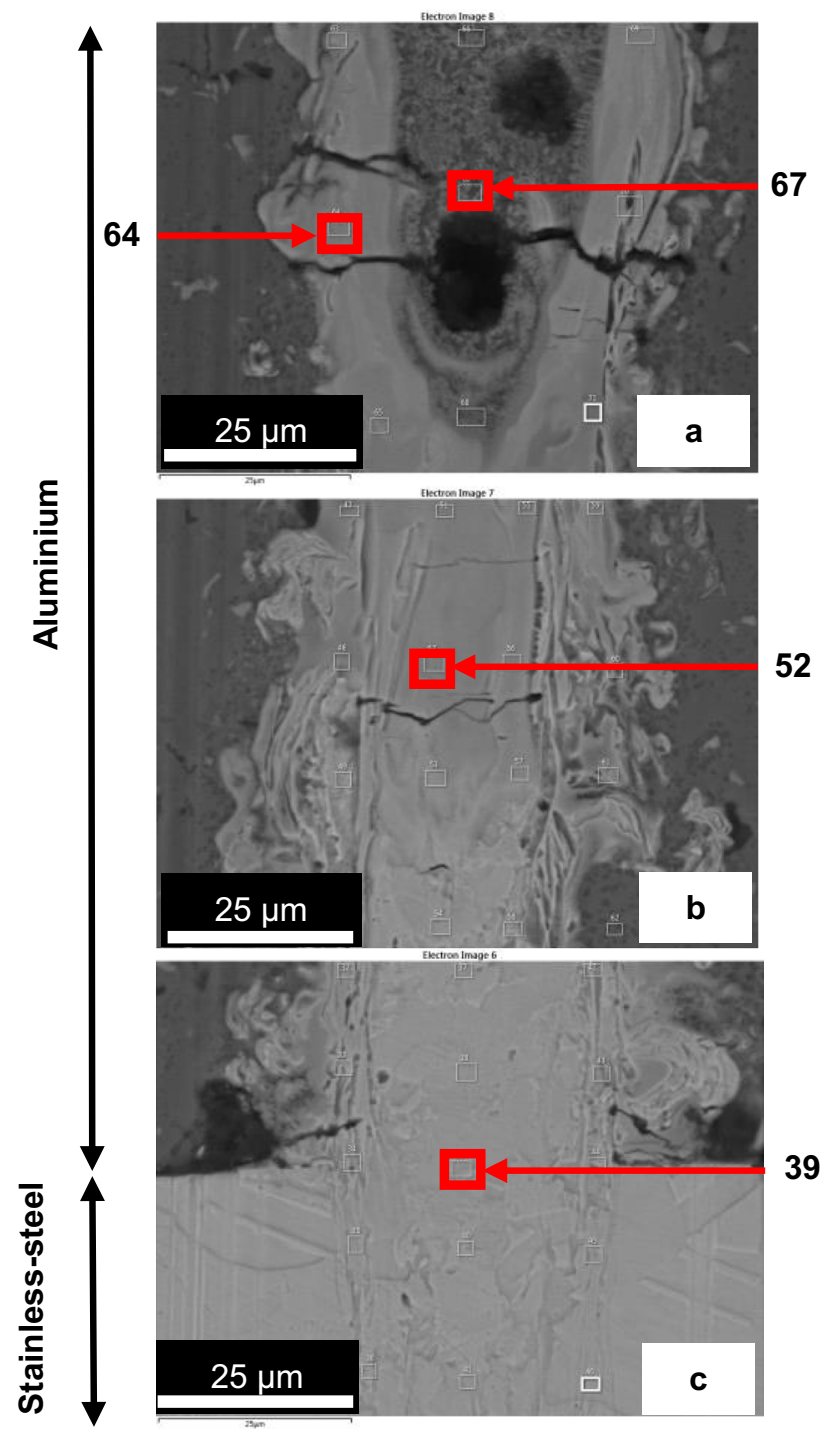

Fig. 14 SEM micrographs from a PW lap joint of Al-SS for $q_{p}$ of $10.4 \mathrm{MW} / \mathrm{cm}^{2}, q_{p \text {, peak }}$ of $208 \mathrm{MW} / \mathrm{cm}^{2}, E_{S P \text {, pulse }}$ of $1000 \mathrm{~mJ}$ and $t_{i}$ of $0.5 \mathrm{~ms}$

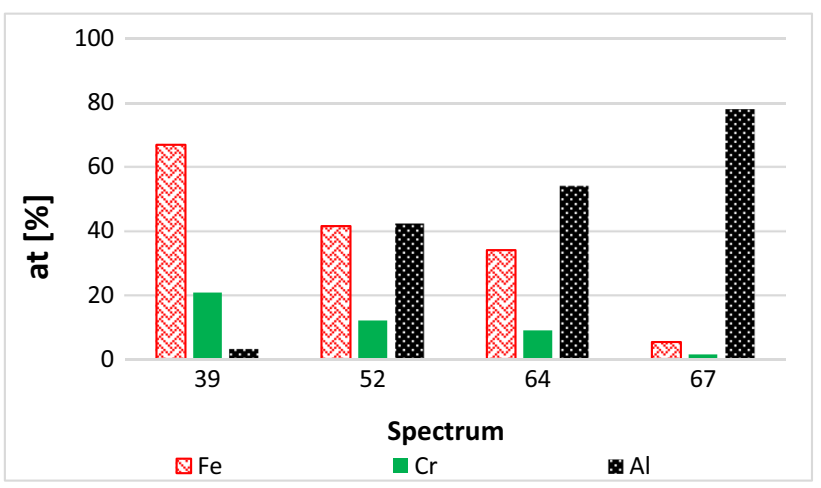

Fig. 15 EDS spectrum analysis from a PW weld of Al-SS for $q_{p}$ of $10.4 \mathrm{MW} / \mathrm{cm}^{2}, q_{p \text {, peak }}$ of $208 \mathrm{MW} / \mathrm{cm}^{2}, E_{S P \text {, pulse }} 1000 \mathrm{~mJ}$ and $t_{i}$ of $0.5 \mathrm{~ms}$

better anchoring effect of the weld-aluminium interface due to higher penetration. On the other hand, since the penetration is deeper for higher energy levels, most of the brittle IMCs are concentrated at the bottom of the weld-aluminium interface, being most of the cracks shifted away from the joint interface, reducing their propagation, as previously explained in "Sect. 5.1". Thus, the remaining cracks will avoid an increase in tensile shear load in the same proportion of the increase of weld lines number.

The tensile shear load versus strain of the strongest and weakest CW welds achieved at $1000 \mathrm{~mJ}$ is shown in Fig. 19 and Fig. 20, respectively. Some loading irregularity is visible due to the variable weld thickness caused by the uneven IMCs distribution along the weld. Despite the shear failure at the metal interface in both figures, higher plastic deformation was achieved with four welds lines, which means the load was distributed evenly to all welds in shear failure mode.

As shown in Fig. 21 for PW mode, the maximum tensile shear load increases with the increase in the number of weld lines and with the $E_{S P}$. A maximum load of $1330 \mathrm{~N}$ was achieved using four weld lines for the energy of $1000 \mathrm{~mJ}$ 


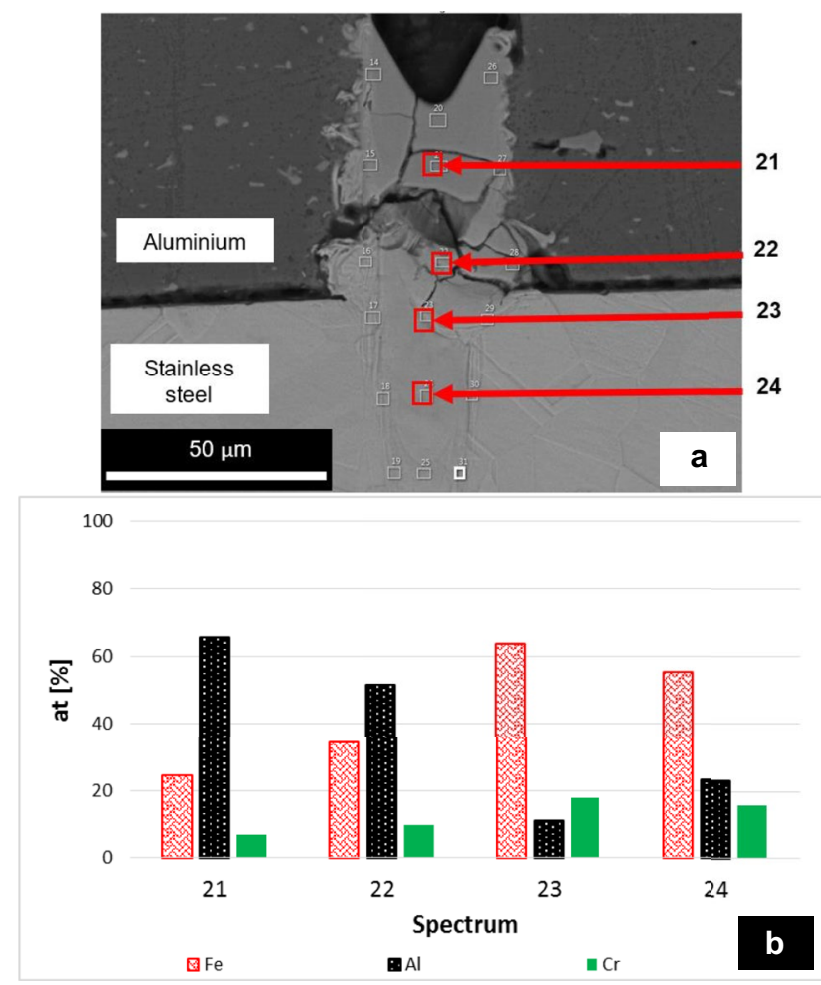

Fig. 16 SEM micrograph (a) and respective EDS spectrum analysis (b) from a PW lap joint of Al-SS for $q_{p}$ of $10.4 \mathrm{MW} / \mathrm{cm}^{2}, q_{p \text {, peak }}$ of $52 \mathrm{MW} / \mathrm{cm}^{2}, E_{S P}$, pulse of $250 \mathrm{~mJ}$ and $t_{i}$ of $0.5 \mathrm{~ms}$

and an interaction time of $0.5 \mathrm{~ms}$. Contrary to what was observed in CW mode, the increase in tensile shear load with the applied energy is not related to the increase of the bonding area since the PW weld width remained almost constant for different energy levels, as previously shown in Fig. 12. For a constant weld width, a higher applied energy will force a larger volume of SS to push Al through a narrow channel, preventing the defects caused by the brittle IMCs at the joint interface. Consequently, this mechanism allows an increase in the load-bearing capacity of PW welds.

The tensile shear load versus strain of the strongest and weakest PW welds achieved at $1000 \mathrm{~mJ}$ are shown in Fig. 22 and Fig. 23, respectively. Like the observations in CW mode, the PW welds failed at the metal interface in both cases and more plastic deformation was achieved with four weld lines in Fig. 22. However, the plastic deformation was higher than in CW mode due to the absence of IMCs at the weld joint, which is well correlated with the observations in Fig. 14 and Fig. 15.

\subsubsection{Tensile shear strength of CW and PW joints}

In Fig. 24, the tensile shear strength of CW welds was calculated by dividing the maximum tensile shear load by the bonding area (weld width multiplied by the total weld length). Increasing $E_{S P}$ from 333 to $1000 \mathrm{~mJ}$ at a constant $q_{p}$ of $33 \mathrm{MW} / \mathrm{cm}^{2}$, the load per unit of weld metal area remained similar for each weld pattern. Thus, the advantage of a larger bonding area for higher values of specific pulse energy may have a threshold to improve the load-bearing capacity, as further IMCs growth would outweigh the advantage of the higher wetting area, decreasing the linear strength from a certain threshold, as shown by Sierra et al. [22]. These results suggest that it is difficult to further improve the mechanical strength of the joints by solely controlling the energy of the process, as also observed by Meco et al. [21], but a definite answer would need more experiments. They concluded that the bonding area is one of the key factors for the integrity of the $\mathrm{Fe}-\mathrm{Al}$ joints and the mechanical strength of the joints could not be improved by increasing the bonding through power density since it is the parameter that most controls the temperature and consequently, the IMC growth would be enhanced. However, the authors suggested that by producing parallel weld seams, the bonding area could be increased, avoiding the negative effect of the IMCs. That strategy was used in this work in Fig. 21 and has revealed to be successful.

In Fig. 25, the tensile shear strength of PW welds increases with $E_{S P \text {, pulse }}$ but not with the number of weld lines. The advantage of a larger bonding area achieved through a longer weld length may have a threshold to improve the load-bearing capacity. This observation may be explained by the variation of IMCs agglomeration along the joint interface, creating weaker points that decrease the linear strength from a certain weld length threshold. Due to the narrower PW welds, the tensile shear strength can be almost $5 \times$ higher than $\mathrm{CW}$ welds. This highlights once again the importance of the pulse shape in controlling the temperature distribution in the processed metal [44]. For high peak power, the heat is quickly transferred to the material and a keyhole is formed, increasing the laser absorptivity [45]. On the other hand, the short pulse duration provides fast freezing of the melt pool, which avoids the heat diffusion by conduction, leading to higher aspect ratio welds, low heat-affected zone, precise control of the heat input and limited growth of the IMCs in comparison to $\mathrm{CW}$ mode. Therefore, if the welding application requires a higher fit-up tolerance and productivity, CW laser is more indicated. The higher average power and the constant and lower peak power provide a stable heat conduction mechanism, which results in larger welds [46].

The addition of many narrower welds using low power density and energy levels above $333 \mathrm{~mJ}$ allowed equivalent 
Fig. 17 PW and CW lap joints of Al-SS for a penetration depth of $1.6 \mathrm{~mm}$ and $t_{i}$ of $0.5 \mathrm{~ms}$
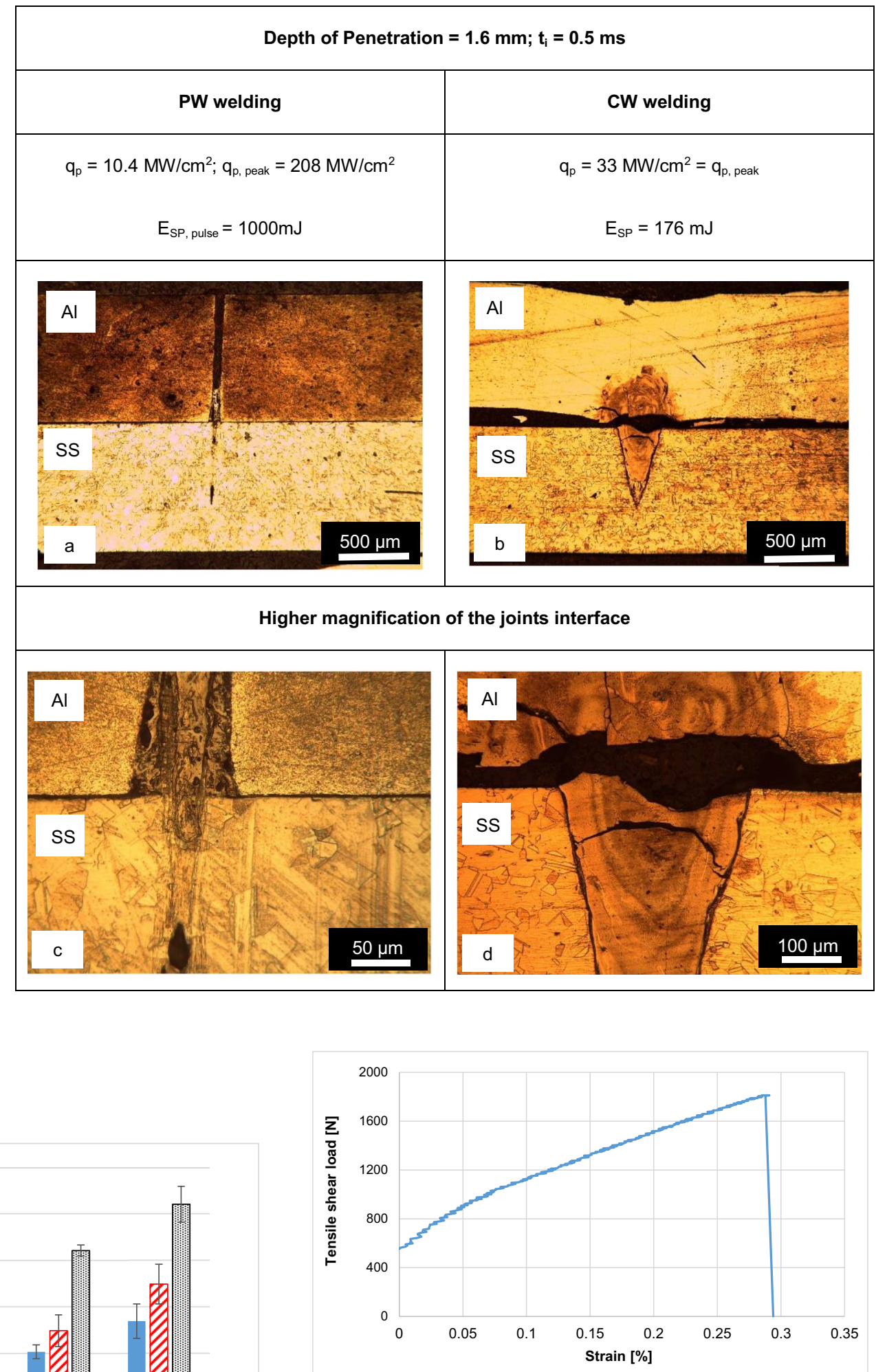

Fig. 19 Tensile shear load versus strain of CW lap joints of SS-Al for $q_{p}$ of $33 \mathrm{MW} / \mathrm{cm}^{2}$ and $E_{S P}$ of $1000 \mathrm{~mJ}$ (4 weld lines)

Fig. 18 Tensile shear load versus $E_{S P}$ of CW lap joints of SS-Al for $q_{p}$ of $33 \mathrm{MW} / \mathrm{cm}^{2}$ 


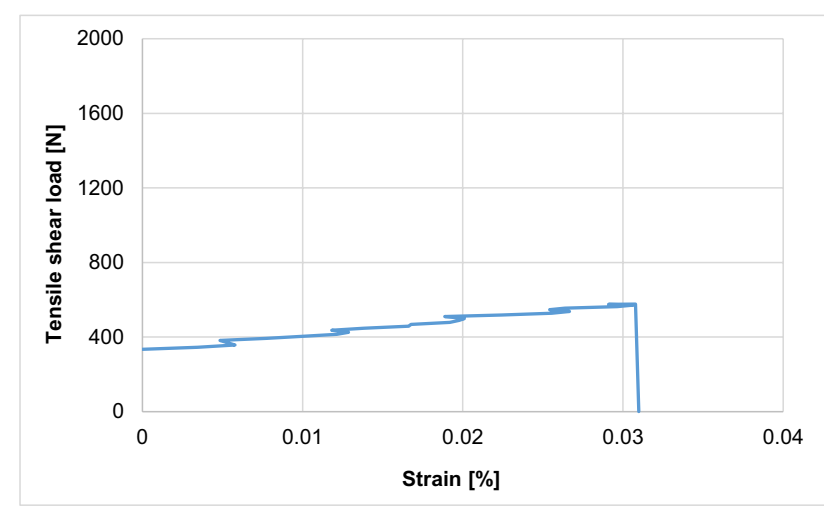

Fig. 20 Tensile shear load versus strain of CW lap joints of SS-Al for $q_{p}$ of $33 \mathrm{MW} / \mathrm{cm}^{2}$ and $E_{S P}$ of $1000 \mathrm{~mJ}$ (1 weld line)

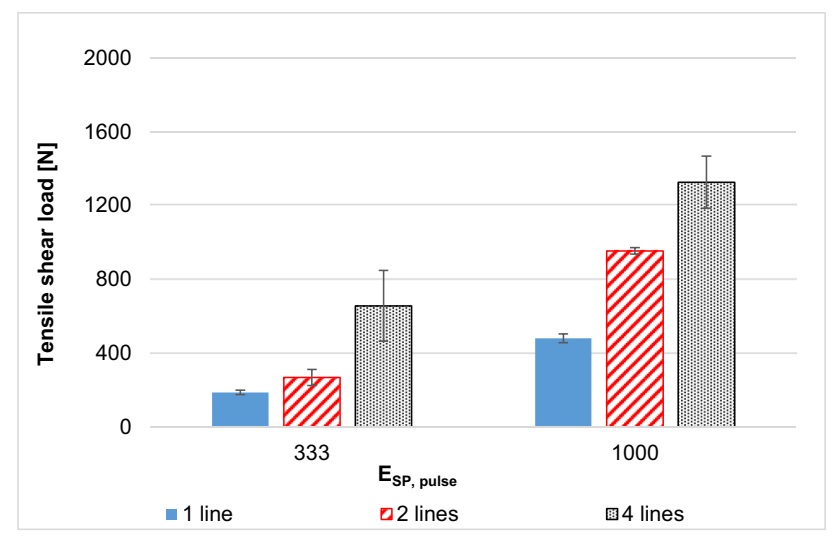

Fig. 21 Tensile shear load versus $E_{S P \text {, pulse }}$ of PW lap joints of Al-SS

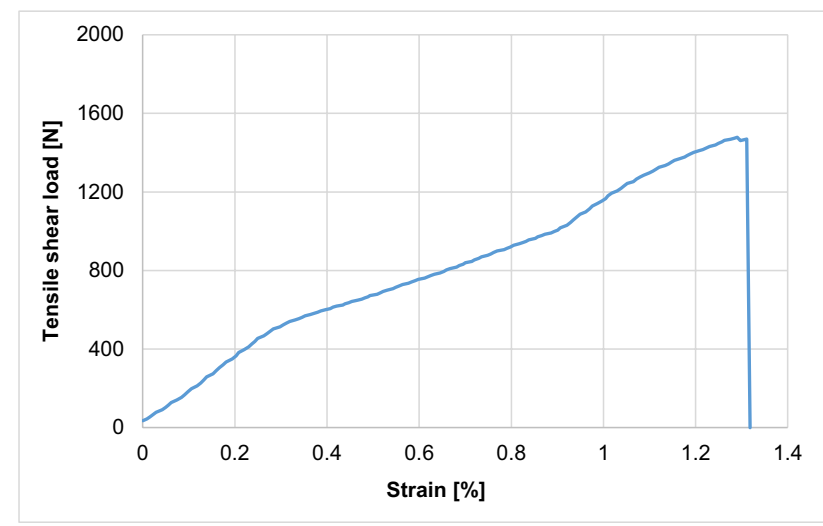

Fig. 22 Tensile shear load versus strain of PW lap joints of Al-SS for $E_{S P}$ of $1000 \mathrm{~mJ}$ (4 weld lines)

bonding areas to $\mathrm{CW}$ and localised diffusion of $\mathrm{Fe}$ into $\mathrm{Al}$, pushing the IMCs out to the fusion zone in Al-SS joints. Thus, for similar applied energy of $1000 \mathrm{~mJ}$ and using four weld lines, an ultimate tensile strength (UTS) of $332 \mathrm{MPa}$

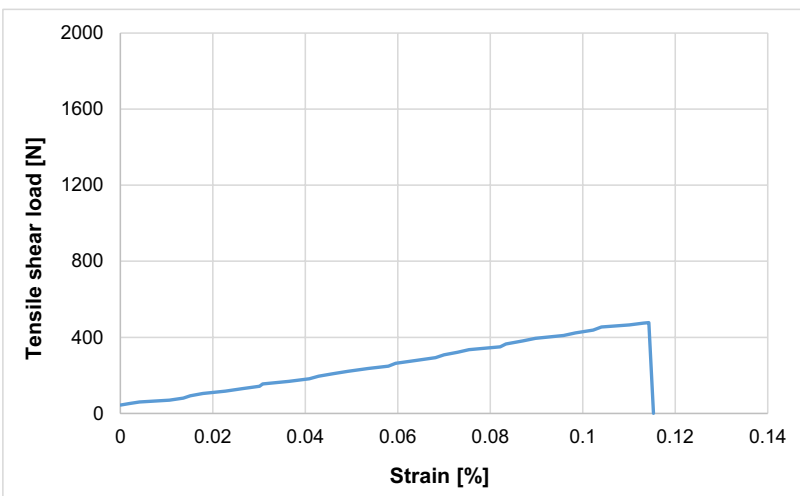

Fig. 23 Tensile shear load versus strain of PW lap joints of Al-SS for ESP of $1000 \mathrm{~mJ}$ (1 weld line)

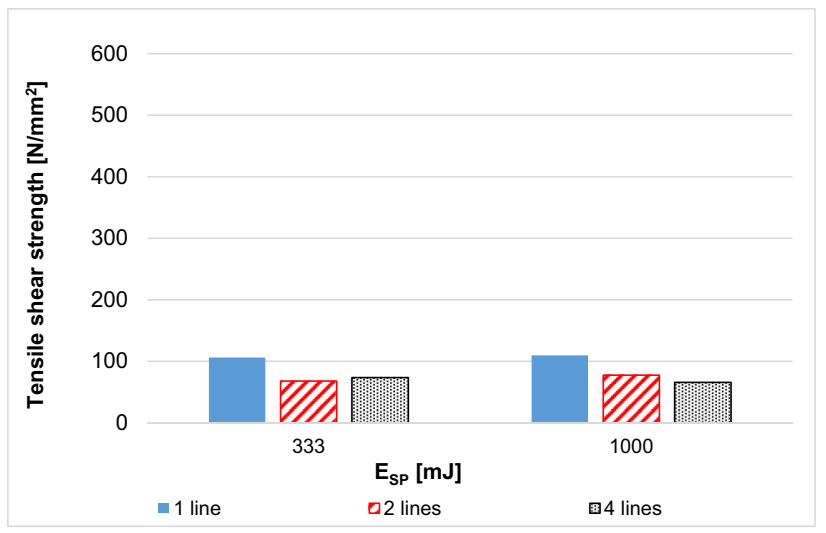

Fig. 24 Tensile shear strength versus $E_{S P}$ of CW lap joints of SS-Al for $q_{p}$ of $33 \mathrm{MW} / \mathrm{cm}^{2}$

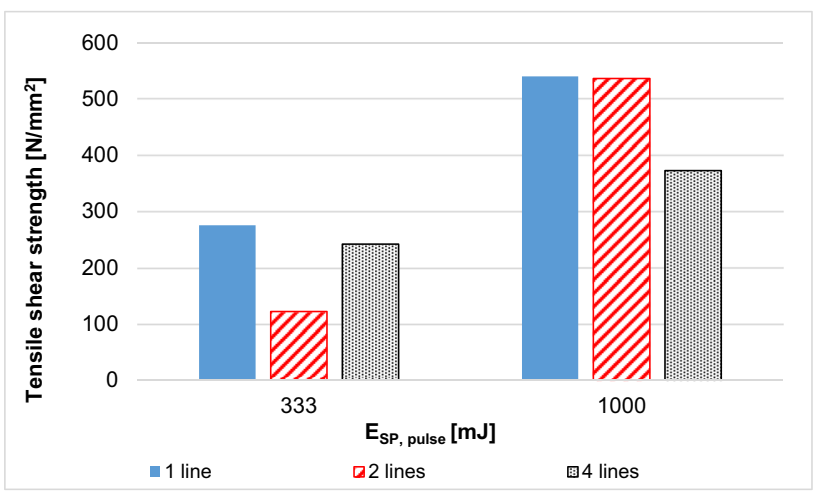

Fig. 25 Tensile shear strength versus $E_{S P \text {, pulse }}$ of PW lap joints of Al-SS

was possible in Al-SS joints for PW mode, whereas in SS-Al $\mathrm{CW}$ welds it was only possible $65 \mathrm{MPa}$ for the same conditions. This reveals that PW welds can be nearly $5 \times$ stronger than the weakest parent metal (Al) showed in Table 2. 
In both laser temporal modes, it was impossible to control the brittle IMCs formation for the range of parameters tested. CW laser was harder to decouple temperature from the melt area, which created a high concentration and more scattered IMCs in the fusion zone, especially for Al-SS joints where there was a high diffusion of Fe to the wider Al weld. On the other hand, for PW laser, there was more flexibility in reducing the alloys mixing and increase the weld strength by minimising the IMC formation through the faster freezing of the weld pool. The thermal cycle was so short and the energy application so fast that no intermetallic pattern has been observed using a standard optical microscope. However, in previous studies [21, 47], evident IMCs patterns have been observed in CW mode even with low magnifications due to the higher energy application and longer thermal cycle by defocusing the laser beam. In both situations, a sparse solid solubility has also been observed, which resulted in a brittle intermetallic formation, but in different scales/dimensions in comparison to the results observed in this work.

The limitation imposed by the melting temperature of these alloys, maximum weld width and penetration depth on the IMCs growth and distribution in the weld fusion zone, creates a limit on the laser parameters selection to maximise the tensile shear load. Thus, several combinations of energy and power density can be used to achieve similar welds, but the maximum tensile shear strength can only be achieved for a certain weld shape for these alloys and thicknesses. Larger beam diameters and different weld patterns could be used to increase even more the bonding area and consequently, the weld strength. In PW mode, it could also be explored shorter pulse durations to provide higher peak power density to push completely the IMCs out of the welding zone.

\section{Conclusions}

- The SS-Al lap joints were successful in CW mode but unsuccessful using a PW laser.

- The Al-SS lap joints were successful using a PW laser, but unsuccessful in CW mode.

- For similar applied energy and number of weld lines, the maximum tensile shear loads were higher in CW than in PW laser welding. However, for the strongest weld, the UTS was five times higher in PW mode.

- CW laser provides better higher fit-up tolerance and productivity. On the other hand, lower heat-affected zone, more precise control of the heat input and high aspect ratio welds can be achieved in PW mode.

- Further investigation using larger beam diameters and different weld patterns is recommended to increase the bonding area and consequently, the weld strength. In PW mode, different pulse durations could also be explored.

\section{Appendix. Equipment for laser characterisation}

The lasers' optical properties, such as beam diameter, focal position, and depth of focus, were measured using a DataRay slit-scan beam profiler shown in Fig. 26. To protect the slit-scan from excessive energy density, the laser average power was reduced to $1 \mathrm{~W}$ and two mirrors were used to deflect the beam and absorb most of the remaining energy. The measurements were done in increments of $0.25 \mathrm{~mm}$, moving the laser in the opposite direction of the beam profiler. The Gaussian profiles generated from both $\mathrm{CW}$ and $\mathrm{PW}$ lasers are shown in Fig. 27 and Fig. 28, respectively, and the beam profiles are presented in Fig. 29.

The laser output power was measured by a laserpoint power meter. The beam was distributed all over the sensor to avoid thermal damage and ensure the acquisition of accurate measurements. It was used to calibrate the real laser output power, showing less than $1 \%$ variation in comparison to the average power shown in the software of the laser source, from $1 \mathrm{~W}$ to the maximum average power available in increments of $10 \mathrm{~W}$. A schematic diagram of the power meter setup is shown in Fig. 30.

Author contribution Julio Coroado - PhD student. He has designed and produced the experimental work in consultation with the other coauthors and is the principal author of the manuscript. Supriyo Ganguly - Reader. He helped in creation of research methodology, experimental work and provided the very essential research direction. Supriyo took active participation in preparing the manuscript. Stewart Williams Professor and chair of the welding engineering and laser processing centre. He also participated actively in experimental design, data analysis and interpretation. Wojciech Suder - Lecturer. As one of the laser experts, Wojciech provided important knowledge on the design of the experimental work and manuscript discussion. Sonia Meco - Senior Research Fellow. Sonia participated in the manuscript checking and correction. Goncalo Pardal - Senior Research Fellow. Goncalo also took active participation in data analysis, manuscript checking and correction.

Funding The researchers would like to acknowledge Innovate UK (TS/ MO11089/1) for sponsoring this investigation in the scope of the Environmental Domed End project.

\section{Declarations}

Ethics approval To the author's knowledge, this is the first paper showing how the penetration and weld width of stainless-steel resultant from the laser welding process is controlled by the pulse power factor and interaction time. The authors confirm that this manuscript has not been published elsewhere and is not under consideration by another journal. The publication of this manuscript has also been approved by all the co-authors.

Consent for publication The author transfers to Springer (respective to owner if other than Springer and for U.S. government employees: to the extent transferable) the non-exclusive publication rights and he 
Fig. 26 Experimental setup for beam profiling
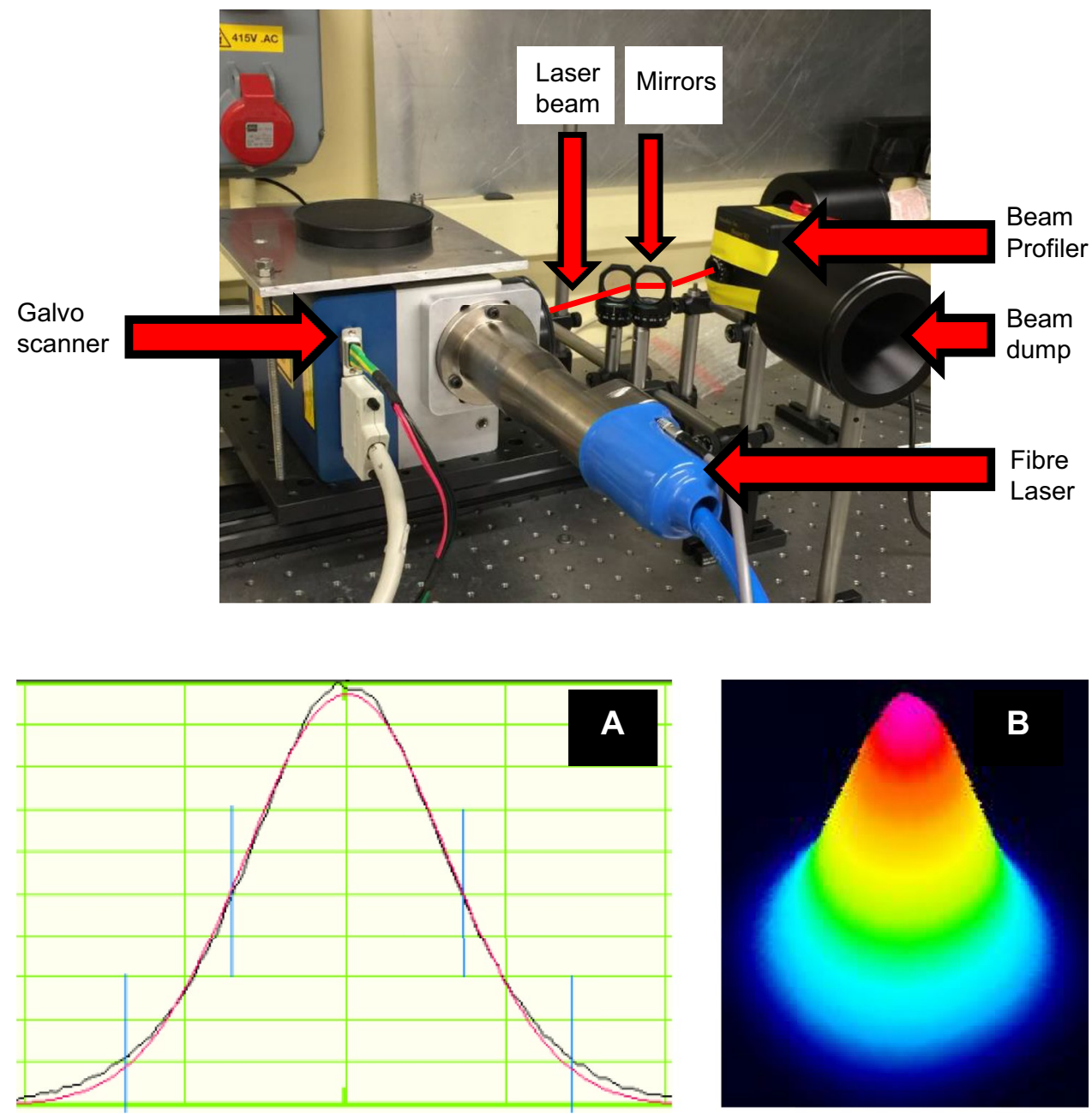

Fig. 27 Gaussian profile (A) and $3 \mathrm{D}$ profile $(\mathrm{B})$ of the $\mathrm{CW}$ laser for a beam diameter of $35 \mu \mathrm{m}$

Fig. 28 Gaussian profile (A) and $3 \mathrm{D}$ profile $(\mathrm{B})$ of the $\mathrm{PW}$ laser for a beam diameter of $35 \mu \mathrm{m}$

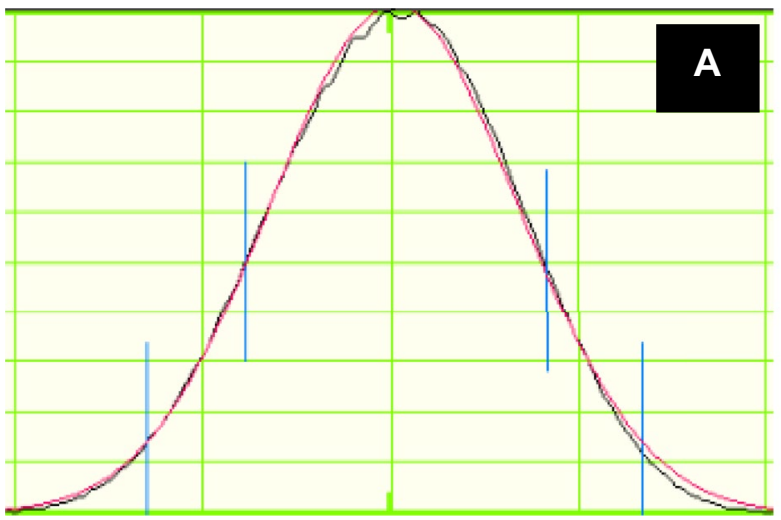

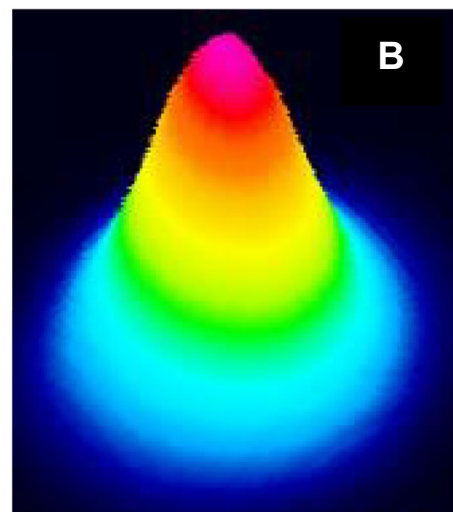

warrants that his contribution is original and that he has full power to make this grant. The author accepts responsibility for releasing this material on behalf of any and all co-authors. This transfer of publication rights covers the non-exclusive right to reproduce and distribute the article, including reprints, translations, photographic reproductions, microform, electronic form (offline, online) or any other reproductions of similar nature. The author may self-archive an author-created version of his article on his own website and his institution's repository, including his final version; however, he may not use Springer's PDF version which is posted on www.springerlink.com. Furthermore, the author may only post his version provided acknowledgement is given to the Journal and Springer as one of the original places of publication and a link is inserted to the published article on Springer's website.

Conflict of interest The authors declare no competing interests. 
Fig. 29 Beam profiles of (A) $\mathrm{CW}$ and (B) PW lasers

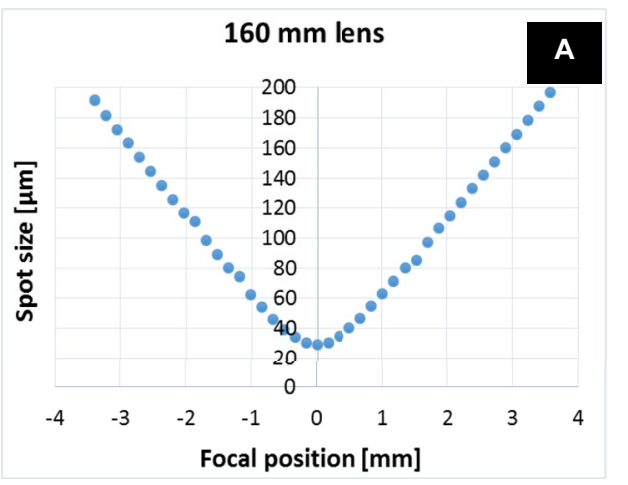

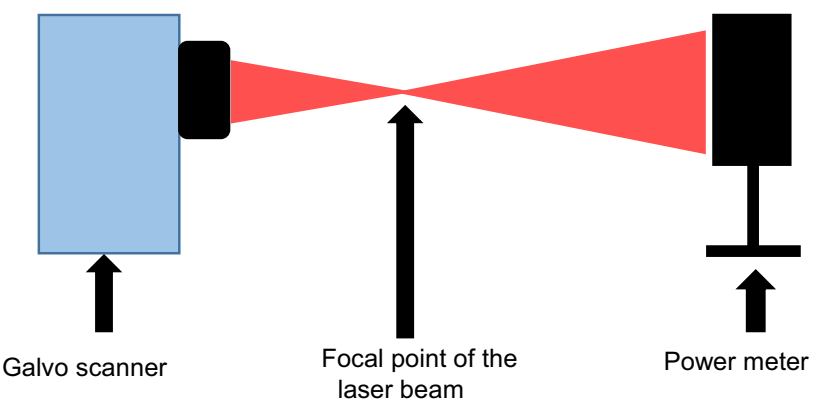

Fig. 30 Schematic diagram of the power meter setup

Open Access This article is licensed under a Creative Commons Attribution 4.0 International License, which permits use, sharing, adaptation, distribution and reproduction in any medium or format, as long as you give appropriate credit to the original author(s) and the source, provide a link to the Creative Commons licence, and indicate if changes were made. The images or other third party material in this article are included in the article's Creative Commons licence, unless indicated otherwise in a credit line to the material. If material is noincluded in the article's Creative Commons licence and your intended use is not permitted by statutory regulation or exceeds the permitted use, you will need to obtain permission directly from the copyright holder. To view a copy of this licence, visit http://creativecommons.org/licenses/by/4.0/.

\section{References}

1. Zwicker MFR, Moghadam M, Zhang W, Nielsen CV (2020) Automotive battery pack manufacturing - a review of battery to tab joining. J Adv Join Process 1:100017. https://doi.org/10.1016/j. jajp.2020.100017

2. Springer H, Kostka A, Payton EJ et al (2011) On the formation and growth of intermetallic phases during interdiffusion between low-carbon steel and aluminum alloys. Acta Mater. https://doi.org/ 10.1016/j.actamat.2010.11.023

3. Song JL, Lin SB, Yang CL et al (2009) Spreading behavior and microstructure characteristics of dissimilar metals TIG weldingbrazing of aluminum alloy to stainless steel. Mater Sci Eng A. https://doi.org/10.1016/j.msea.2009.02.036

4. Borrisutthekul R, Yachi T, Miyashita Y, Mutoh Y (2007) Suppression of intermetallic reaction layer formation by controlling heat flow in dissimilar joining of steel and aluminum alloy. Mater Sci Eng A. https://doi.org/10.1016/j.msea.2007.03.049

5. Shahverdi HR, Ghomashchi MR, Shabestari S, Hejazi J (2002) Microstructural analysis of interfacial reaction between molten aluminium and solid iron. J Mater Process Technol. https://doi. org/10.1016/S0924-0136(02)00225-X

6. Lee WB, Schmuecker M, Mercardo UA et al (2006) Interfacial reaction in steel-aluminum joints made by friction stir welding. Scr Mater. https://doi.org/10.1016/j.scriptamat.2006.04.028

7. Soltan Ali Nezhad M, Haerian Ardakani A (2009) A study of joint quality of aluminum and low carbon steel strips by warm rolling. Mater Des. https://doi.org/10.1016/j.matdes.2008.06.042

8. W M Thomas, D J Staines, I M Norris SAW and CSW (2006) Transition Joints between dissimilar materials. TWI Ltd Granta Park Gt Abingt Cambridge CB1 6AL United Kingdom 1-7

9. Meco S, Ganguly S, Williams S, McPherson N (2014) Effect of laser processing parameters on the formation of intermetallic compounds in $\mathrm{Fe}-\mathrm{Al}$ dissimilar welding. J Mater Eng Perform 23:3361-3370. https://doi.org/10.1007/s11665-014-1106-5

10. Liu XB, Pang M, Zhang ZG et al (2007) Characteristics of deep penetration laser welding of dissimilar metal Ni-based cast superalloy K418 and alloy steel 42CrMo. Opt Lasers Eng. https://doi.org/10.1016/j.optlaseng.2007.03.004

11. Li Y, Liu Y, Yang J (2020) First principle calculations and mechanical properties of the intermetallic compounds in a laser welded steel/aluminum joint. Opt Laser Technol. https://doi.org/ 10.1016/j.optlastec.2019.105875

12. Palm M (1997) The Al-Cr-Fe system-phases and phase equilibria in the Al-rich corner. J Alloys Compd. https://doi.org/10. 1016/S0925-8388(96)02719-3

13. Quazi MM, Ishak M, Fazal MA et al (2020) Current research and development status of dissimilar materials laser welding of titanium and its alloys. Opt Laser Technol 126:106090. https:// doi.org/10.1016/j.optlastec.2020.106090

14. Cao X, Wallace W, Immarigeon J-P, Poon C (2003) Research and progress in laser welding of wrought aluminum alloys. II. Metallurgical Microstructures, Defects, and Mechanical Properties. Mater Manuf Process 18:23-49. https://doi.org/10.1081/ AMP-120017587

15. Zang Z, Zeng X, Du J et al (2016) Femtosecond laser direct writing of microholes on roughened $\mathrm{ZnO}$ for output power enhancement of InGaN light-emitting diodes. Opt Lett 41:34633466. https://doi.org/10.1364/OL.41.003463

16. Huang H, Yang L-M, Bai S, Liu J (2014) Femtosecond fiber laser welding of dissimilar metals. Appl Opt. https://doi.org/ 10.1364/ao.53.006569

17 Yang J, Li YL, Zhang H (2016) Microstructure and mechanical properties of pulsed laser welded Al/steel dissimilar joint. Trans 
Nonferrous Met Soc China English Ed. https://doi.org/10.1016/ S1003-6326(16)64196-1

18. Pardal G, Meco S, Dunn A et al (2017) Laser spot welding of laser textured steel to aluminium. J Mater Process Technol 241:24-35. https://doi.org/10.1016/j.jmatprotec.2016.10.025

19. Meco S, Pardal G, Ganguly S et al (2013) Overlap conduction laser welding of aluminium to steel. Int J Adv Manuf Technol 67:647-654. https://doi.org/10.1007/s00170-012-4512-6

20. Meco S, Ganguly S, Williams S, McPherson N (2019) Design of laser welding applied to $\mathrm{T}$ joints between steel and aluminium. $\mathrm{J}$ Mater Process Technol 268:132-139. https://doi.org/10.1016/j. jmatprotec.2019.01.003

21. Meco S, Cozzolino L, Ganguly S et al (2017) Laser welding of steel to aluminium : thermal modelling and joint strength analysis. J Mater Process Tech 247:121-133. https://doi.org/10.1016/j. jmatprotec.2017.04.002

22. Sierra G, Peyre P, Deschauxbeaume F et al (2007) Steel to aluminium key-hole laser welding. Mater Sci Eng A 447:197-208. https://doi.org/10.1016/j.msea.2006.10.106

23. Torkamany MJ, Malek Ghaini F, Poursalehi R, Kaplan AFH (2016) Combination of laser keyhole and conduction welding: dissimilar laser welding of niobium and Ti-6Al-4V. Opt Lasers Eng. https://doi.org/10.1016/j.optlaseng.2015.11.001

24. Suder WJ, Williams SW (2012) Investigation of the effects of basic laser material interaction parameters in laser welding. $\mathbf{J}$ Laser Appl 24:032009. https://doi.org/10.2351/1.4728136

25. Coroado J, Meco S, Williams S et al (2017). Fundamental understanding of the interaction of continuous wave laser with aluminium. https://doi.org/10.1007/s00170-017-0702-6

26. Banat D, Ganguly S, Meco S, Harrison P (2020) Application of high power pulsed nanosecond fibre lasers in processing ultra thin aluminium foils. Opt Lasers Eng 129:106075. https://doi.org/10. 1016/j.optlaseng.2020.106075

27. Williams S, Suder W (2011) Use of fundamental laser material interaction parameters in laser welding. CLEO 2011 - Laser Sci to Photonic Appl 1-2

28. John A (2015) Dissimilar welding of stainless steel to aluminium thin sheet using nano-second pulsed fibre laser. Dissertation, Cranfield University

29. Alsaidi M, Caballero A, Eze S, et al (2015) Study of laser metal interaction for pulsed nanosecond fibre laser. Dissertation, Cranfield University

30. Coroado J, Ganguly S, Suder W et al (2021) Selection of parameters in nanosecond pulsed wave laser micro-welding. Int $\mathbf{J} \mathrm{Adv}$ Manuf Technol. https://doi.org/10.1007/s00170-021-07251-8

31. TRUMPF (2014) $100 \mathrm{~W}$ G4 pulsed fibre laser specification interface manual TRUMPF. Lasers UK Ltd, Southampton

32. Chmelickova H, Ctvrtlik R, Stranyanek M (2004) Pulsed laser welding of thin metals. In: Proc. SPIE 5445, Microwave and Optical Technology. pp 356-359
33. aalco (2019) Aluminium alloy 5251 - H22 sheet and plate properties. http://www.aalco.co.uk/datasheets/Aluminium-Alloy-5251H22-Sheet-and-Plate_150.ashx. Accessed 1 Oct 2019

34. aalco (2019) Stainless steel - austenitic - 304L properties. http:// www.aalco.co.uk/datasheets/Stainless-Steel-14301-Sheet-andPlate-Quarto-Plate--CPP-Plate_343.ashx. Accessed 1 Oct 2019

35. Suder W (2011) Study of fundamental parameters in hybrid laser welding. Dissertation, Cranfield University

36. Meco S (2016) Joining of steel to aluminium alloys for advanced structural applications. Dissertation, Cranfield University

37. British Standard Institution (2001) BS EN ISO 14273:2001 Specimen dimensions and procedure for shear testing resistance spot, seam and embossed projection welds. London

38. Qiu R, Iwamoto C, Satonaka S (2009) Interfacial microstructure and strength of steel/aluminum alloy joints welded by resistance spot welding with cover plate. J Mater Process Technol 209:41864193. https://doi.org/10.1016/j.jmatprotec.2008.11.003

39. Olsen FO (2009) Hybrid laser arc welding. Hybrid laser-arc welding, 1st edn. CRC Press, Boca Raton, pp 270-295

40. Lee SJ, Nakamura H, Kawahito Y, Katayama S (2014) Effect of welding speed on microstructural and mechanical properties of laser lap weld joints in dissimilar $\mathrm{Al}$ and $\mathrm{Cu}$ sheets. Sci Technol Weld Join 19:111-118. https://doi.org/10.1179/1362171813Y. 0000000168

41. Massalski T (1986) Binary alloy phase diagrams, American S. Williams, Jr. W. Scott, Metals Park, Ohio

42. Xiao R, Zhang X (2014) Problems and issues in laser beam welding of aluminum-lithium alloys. J Manuf Process 16:166-175. https://doi.org/10.1016/j.jmapro.2013.10.005

43. Indhu R, Divya S, Tak M, Soundarapandian S (2018) Microstructure development in pulsed laser welding of dual phase steel to aluminium alloy. In: Procedia Manufacturing

44. Baruah M, Bag S (2017) Influence of pulsation in thermo-mechanical analysis on laser micro-welding of Ti6Al4V alloy. Opt Laser Technol 90:40-51

45. Assuncao E, Williams S (2014) Effect of material properties on the laser welding mode limits. J Laser Appl 26:012008. https:// doi.org/10.2351/1.4826153

46. Kuo TY, Lin HC (2006) Effects of pulse level of Nd-YAG laser on tensile properties and formability of laser weldments in automotive aluminum alloys. Mater Sci Eng A 416:281-289. https://doi. org/10.1016/j.msea.2005.10.041

47. Meco S, Pardal G, Ganguly S, Miranda RM (2013) Overlap conduction laser welding of aluminium to steel. Int J Adv Manuf Technol 647:654. https://doi.org/10.1007/s00170-012-4512-6

Publisher's note Springer Nature remains neutral with regard to jurisdictional claims in published maps and institutional affiliations. 


\title{
Comparison of continuous and pulsed
} wave lasers in keyhole welding of pÿstainless steel to aluminium

\author{
Coroado, Julio
}

Springer

Coroado J, Ganguly S, Williams S, et al., (2022) Comparison of continuous and pulsed wave pÿlasers in keyhole welding of stainless steel to aluminium. International Journal of Advanced pÿManufacturing Technology, Volume 119, Issue 1-2, March 2022, pp. 367387

https://doi.org/10.1007/s00170-021-08226-5

Downloaded from Cranfield Library Services E-Repository 